\title{
The National Question
}

Prior to the outbreak of World War I, the national question was a pressing concern for Austrian Social Democracy. Quarrels and national conflicts not only jeopardised the existence and stability of the Austro-Hungarian monarchy, they also made it more difficult to achieve the primary objective Social Democracy had set for itself: maintaining the unity of the working-class movement in a multi-ethnic state. As Austrian activists and leaders of the European labour movement became aware, it would be impossible to design a coherent and realistic nationalities programme if arguments insufficiently discussed by the classical Marxists remained unsolved. ${ }^{1}$ Among these were, for instance, the essence of the nation, traits that constitute a nation, and the relationship between society, nation, and state. In his early work, The Question of Nationalities and Social Democracy (1907), Bauer attempted to solve these, as well as related issues. He intended the text as a draft for a Social-Democratic political programme on the nationalities question under the Habsburg monarchy. ${ }^{2}$ In way of a preliminary study, Bauer's text also contained remarkable sociological theory, which granted it a place in the canon of classic contributions on the so-called 'national question.3

1 The classical Marxists did not codify a definition of the nation. It is possible to conclude from their texts on the Jewish question, pan-Slavism, colonialism, and the right of oppressed nations to independence that they conceived of the nation as a product of economic, social, and political relations rooted in territory and language. In their positions on the national question, the classical Marxists instead favoured social revolution and the class interest of the proletariat in the struggle for social and political liberation.

2 Bauer's observations on the essence of the nation, its constitutive factors, and determinants in the process of nation formation were the first Marxist interpretations of the national question on a European scale. The book consists of four thematic units: (1) the nation as a concept, (2) the nation state, (3) the multi-ethnic Habsburg state, (4) the nationalities programme of Social Democracy.

3 The text provoked controversy among Marxists when its author was still alive, and it continues to do so today. Kautsky and Stalin immediately rebuked it. Bauer's theory of the nation also provoked vivid debate in the Polish socialist camp. Mieczysław Niedziałkowski was directly influenced by it, while Leon Wasilewski evaluated it critically. See Kautsky 1917, 2009 and 2010; Stalin 1913 and 2003; Niedziałkowski 1926 and 1943; and Wasilewski 1929. For testimony

(C) EWA CZERWIŃSKA-SCHUPP, 2017 | DOI: 10.1163/9789004325838_005 
Bauer was mindful of the difficulties and limitations he would face when formulating the premises of his theory of the nation, as a medley of divergent ideas as to what actually made a nation apprised the social consciousness of the period. In addition, hard science - biology and psychology in particular was still relatively undeveloped. He drew inspiration from two sources: Karl Lamprecht's Deutsche Geschichte (German History, 1891-1908) and the works of Marx, namely The Eighteenth Brumaire of Louis Napoleon. Drawing on the analytical method of historical materialism, Bauer created a concept of the nation that was sharply antagonistic towards the idealist conceptions within romantic nationalist ideology, racist constructs with biological inclinations, and empirical as well as psychological theories (his concept was saturated with psychologism, despite claims to the contrary). ${ }^{4}$ Bauer also criticised the antiSemitism present in German and Austrian Social Democracy and polemicised against those who declared, like Kautsky and Werner Sombart, that a nation was defined by common language and territory. ${ }^{5} \mathrm{He}$ observed that there existed not only distinct nations that spoke a common language, but also conquered nations that preserved their distinct nationality while embracing the language of the invader. Bauer found that it was not possible to grasp the essence of a nation merely by listing traits commonly associated with the term. When making use of the theoretical sources and basic methodological premises of Marxism to develop his concept, he defied orthodox Marxism and its fundamental object-subject opposition. The category of nationality that he introduced was based on social practice in the broader sense, thus continuing the line of logic

as to the different ways in which Bauer's theory of the nation was interpreted, see Konrad 1981, Mozetič 1987, Przestalski 1981, Śliwa 1980 and Wiatr 1973.

4 See Kołakowski 2005, p. 297, and Leser 1968, p. 253. Rooted in romantic ideologies, idealist theories appealed to metaphysical notions of the national soul, frequently accrediting an exceptional mission in human history to the nation (Volksgeist, the influence of Herder and Hegel) - Bauer described these as national spiritualism. Racist theories based on Darwin and Weismann's research suggested the existence of a mysterious reproductive substance. In empirical theories, the nation was understood as a complex of traits such as language, territory, law, morals, religion, economy, and so on; Stalin and Kautsky both conceded to this. Psychological conceptions equated the existence of the nation with a national sense of belonging. According to these, the peasantry was outside of the nation as late as the nineteenth century. Bauer pointed out that after Kant, such psychological approaches lacked any scientific basis.

5 Kautsky did not believe that Jews constituted a nation since they possessed neither territory nor a common language - they were linked merely through religious and group ties. In contrast, Sombart thought that Jews belonged to an entirely different race. See Kautsky 2009 and 2010, and Sombart 1909 . 
in Marx's Capital. The most valuable aspect of his theory was his departure from positivist conceptions of the relationship between humans and their environment. In his analysis of individual factors that make up nationalities - such as economic conditions, political organisation, and culture - he put culture first. Because he deduced culture from practical human actions, his theory was not only descriptive, but also possessed an axiological dimension: national values and national culture played a vital role in the process of nation-forming.

\subsection{The Essence of the National Character}

The essence of a nation - or, to use Bauer's phrase, national community - is determined by a set of interacting social phenomena. This complex is specifically determined by various factors. Of these, he deemed the national character to be the most vital: "The nation is the totality of human beings bound together by a community of fate into a community of character'. ${ }^{6}$ The fact that Bauer conflated the nation with the national character had significant implications for his entire concept, as it shifted the emphasis from the material world onto the sphere of consciousness. What, then, exemplifies the essence of the national character, and why did Bauer ascribe central importance to this category as a qualifier of the nation?

For Bauer, everyday experience is already a good index of the similarities and differences between historically constituted nations. Similar geographical and demographic conditions, the type of economy, and the forms in which political life is institutionalised bind them together. Differences between nations, on the other hand, are usually manifest in disparities of territory and language, as well as different customs, traditions, ideas, diverse mentalities and modes of experiencing the world, and in the production of material and intellectual culture. That neither similar living conditions nor a shared territory and language can always erase national differences in the spheres of law, morals, aesthetics, science and religion inspired Bauer to seek the constitutive characteristics of the nation in the sphere of consciousness. This decisive criterion constituted a 'community of character'. The community of character, according to him, was nothing but the intersubjective sphere of social consciousness that reflected a common mentality, a mode of experience, a way of passing judgement, in short: all that is crucial for the unity of humankind. Bauer understood the concept of character in its enormity. It was a complex of physical and intellectual human attributes, although he thought that physical characteristics were of secondary significance. He established that intellectual and physical traits evolved

6 Bauer 1996, p. 117 . 
through an individual's participation in a variety of social relationships and dependencies. These, in turn, defined specific types of social relations such as class, professional and national relations. It was therefore justified to speak of class character, professional character, and national character as categories that were not mutually exclusive. A German worker, for instance, displayed traits that are typical of Germans, but also characteristics he shared with workers from different countries.

Bauer was conscious of the ambiguity and fluidity of the concept of national character. 'A community of character', he declared, 'links the members of a nation together in a particular era, but it by no means links the nation of our era with its ancestors two or three thousand years ago. ${ }^{7}$ The concept requires further elucidation as science only distinguishes individual types of national character. Bauer rejected perspectives that exemplified the behaviour of individual citizens to illuminate the essence of these types. ${ }^{8}$ This is understandable given the concept of community that Bauer as a sociologist introduced. This approach to research neglected two substantial facts for him: (1) that the community of character is manifest in all, not just specific, actions; and (2) that actions are determined by real, historically distinct social relations. When analysing the distinct national characters of the English and French and their evolution, he focused on differences rooted in national history in the broader sense. According to Bauer, French culture was shaped by the Royal court, whereas in England, the aristocracy and urban patriciate were the enforcers of culture. Hence the divergent status of the ruling classes and their inherent traits such as aesthetics, taste, lifestyle, and intellectual culture subsequently becoming appropriated as standard by other social classes. The two countries, Bauer argued, produced different types of political conventions: English political thought was characterised by traditionalism and a penchant for patriotism, the result of a power struggle waged by the peerage. In this case, the ideology of an emerging class incorporated that of a class in the process of leaving the historical stage. In contrast, France was distinguished by a propensity to revolutionary upheavals, a result of the ruling dynasty's assertion of its power. Here, the new schema of ideas rigorously disassociated itself from the past system. Based on his analysis, the author concluded that the confines of the term 'national character' were extraordinarily broad. In his view, it encompassed state and social life, institutional forms, and the accomplishments of

7 Bauer 1996, pp. 20-1.

8 According to Bauer, Sombart committed this error when claiming that the essence of the Jews' national character was defined by their propensity to abstract thinking. See Sombart 1909, p. 128. 
science, philosophy, poetry and culture. Crucially, Bauer viewed the essence of the national character as primarily determined by cultural heritage. The provenance of the national character, on the other hand, was a matter of secondary importance for him.

However, the question remains as to why a particular type of national character arbitrates a strictly defined range of common behavioural patterns and bonds in the sphere of consciousness. Furthermore, what trait of the national character affords it priority over professional or class character? The answer is in how the national character manifests itself in concrete human actions, and for these, the 'direction of will' (Willensrichtung, a category he introduced under the influence of Max Adler) is significant. According to Bauer, every rational human being makes conscious decisions in the struggle to satisfy their needs. As cogitative subjects, humans regulate the shape of social phenomena, yet at the same time, their being is determined by reality. Every external stimulus triggers a specific type of behaviour, one particular action instead of another. Defending the monist-determinist perception of society, Bauer was prepared to accept that general determination prevailed in the world of social phenomena. Clearly inspired by Max Adler's neo-Kantian disquisitions, Bauer believed that this was rooted in the fact that the individual's will was an expression of the a priori collective will. The collective will, as a form of human consciousness, is subject to the determination process. Individuals form a nation through a unified will. This becomes apparent in the fact that people of the same nation make the same, or at least very similar, choices. When finding themselves in similar situations or being subject to similar factors, they draw on the same system of values:

The will expresses itself even more directly in decision-making. A German and an Englishman act differently in different circumstances and approach the same work in different ways. They choose different pleasures when they wish to enjoy themselves, prefer different lifestyles and satisfy different needs when they share the same level of prosperity. These traits are certainly constitutive of the essence of the national character. ${ }^{9}$

In relation to the world of humans and nature, Bauer regarded the will as the creative force. Consequently, the national character decided the type of actions directed towards other humans and nature (nature being understood as a social category in the Lukácsian sense). In Bauer's estimations, this 'direction

9 Bauer 1996, p. 99. 
of will' was a comprehensive law conditioned by physical and intellectual attributes that were characteristic of all members of a nation. He believed that these evolved in the course of the common struggle for survival and through inheritance of socially acquired traits and cultural assets. In other words, the character of the individual is forged by the same natural and socio-historical factors, yet will as expressed through practical actions is the final instance that determines the nature of the national character. The unified will is the enduring, objective characteristic of the national character.

There was another remarkable aspect to the conception of the national character suggested by Bauer. It became conspicuous whenever he left the terrain of metaphysical observations and dedicated his attention to the empirical reality bound to the existence of concrete nations. Bauer warned of a fetishistic approach towards the national character, i.e. of treating it as an independent historical driving force. He stated that the national character as such did not lead to the emergence of a nation. On the contrary, the existence of a nation provided the foundations for an emerging national character..$^{10}$ The national character, for him, was an empirical truth. Its form was the product not only of historical influences and inheritance of cultural assets, but also of material living conditions, the development of productive forces, and relations of production. In Bauer's view, national consciousness, whose materialisation was a historical process and subject to various conditions, played an active role in recognising this.

\section{2}

The Peculiar Quality of National Consciousness

National consciousness - the specific feeling of commonality and otherness in relation to other nations - is, according to Bauer, a form of social consciousness. It is not the source, but the aftereffect of a process of national integration that can last for centuries. The nature of the actual national bonds which emerge between individuals in a strictly defined historical situation defines the degree to which individuals integrate. Bauer particularly emphasised the inconstant nature of national affinity. This was because, for Bauer, national affinity was rooted in an ever-changing, evolving commonality of historical fate. He perceived the commonality of historical fate as an emotional and psychological community - or, in other words, an enduring structure of emotions and consciousness (which is related to the aforementioned conception of national character). The above observation is fundamental for understanding Bauer's interpretation of the term 'national consciousness'. National affinity - which, 
according to Max Adler, has a transcendental character - is understood as a spiritual, psychological type of affinity. It develops due to actions in which humans are emotionally involved. 'It is not the similarity of fate, but only the shared experience and suffering of a fate, the community of fate, that produces the nation..11 In this sense, some critics were validated in asserting that Bauer was himself inclined towards a psychological theory of the nation, even though he had set out to oppose it. ${ }^{12}$

When defining the essence of national kinship, Bauer neglected, or at least diminished, the role of elements such as emotional attachment to a territory, state, or even blood ties. This is further evidence that, as previously stated, physical ties between individuals were only of secondary value for Bauer. Cultural factors evidently took precedence. Bauer identified culturally constituted intellectual culture - emotional and psychological bonds, legal ties, common customs, religion, language, literature and the arts - as the essence of national affinity. National consciousness unambiguously reflected national affinity, giving expression to the objectivised system of intellectual and cultural achievements of a society organised as a nation. From this perspective, Bauer challenged subjectivist conceptions of national consciousness, i.e. notions according to which the subjective feeling of belonging to a nation was a sufficient criterion for an individual's nationality. To explain the process of emerging national affinity and consciousness, he appealed to science as the one form of social consciousness that utilises objective criteria in analysing and describing social phenomena.

Bauer stressed how slowly the developing process of national consciousness unfolds, highlighting its historical variability and its psychological and sociohistorical prerequisites. According to him, the so-called 'law of inertia', which inhibits all that appears external, new, or alien, slows this process down. ${ }^{13}$ Bauer's analysis of the socio-historical prerequisites for the origins of national consciousness made numerous conclusions that converged with Marxism. He suggested that the content of national consciousness, expressed in the products

\footnotetext{
11 Bauer 1996, pp. 100-1.

12 See Lenin 1977, p. 398; compare Kozyr-Kowalski 1974, p. 327.

13 Bauer distinguished different 'levels' of consciousness induced by the law of inertia. He cited the consciousness of a peasant and that of a modern bourgeois as examples, while emphasising a common trait, namely their conservative inclinations. Bauer viewed their will to preserve the status quo as based on divergent foundations. He argued that the peasants' conservatism had psychological roots in their attachment to the behavioural patterns and norms inherited from their ancestors. For the bourgeois, conversely, class position and the struggle to preserve it were paramount.
} 
of a given country's intellectual culture, illustrates the historically changing objective material conditions of social being. Moreover, the composition of national consciousness expresses the interests of the economically strongest (ruling) class, given that the same historical and economic process that fabricates the basis of class relations also underlies emerging national relations. ${ }^{14}$ Due to the exclusion of certain classes from the national community, national consciousness either had a feudal or bourgeois character in early, pre-capitalist stages of national development. Hence, Bauer correctly observed that the lack of national consciousness might be due to a class's objective existence on the fringes of a nation. For him, a further crucial requirement for the development of national consciousness was general access to cultural assets. His ratification of this criterion per se reflected a perceptive observation: classes and social layers with limited access to culture displayed lower levels of national consciousness. Capitalism managed to conquer this obstacle, giving rise to two new phenomena: steadily growing national consciousness in the ranks of the proletariat and the increasing dominance of national affinity over class solidarity. Bauer was inclined to believe that in the modern capitalist state, national affinity assumed an increasingly harmonious character and was stronger than class bonds. If we consider contemporary struggles for national independence, history seems to confirm this tendency.

As an aside, Bauer's text contained a particular thesis according to which all forms of social consciousness were subject to national determination. From this, it would logically follow that science is also subject to such determination. All the same, Bauer did not deny the objective existence of science as a supra-national form of acquiring knowledge in his other works. This incoherence reflected the intellectual contradictions in which the young Bauer was embroiled. The purpose that he himself ascribed to science - i.e. to explain the foundations of judgement in national categories and assess them critically was ample evidence that he was aware of its objective status.

\footnotetext{
14 Bauer associated the emergence of national consciousness with the advancing process of capitalisation of social and political relations. He claimed that this shift occurs, stage by stage, as society's means of production are revolutionised. However, he was often mistaken and he did not consider increasing exploitation. To offer an example, he argued that the import of goods from Czechia lowered wages for German workers and had other negative effects: in economic terms (Germans had to pay the costs of economic inequality), and in the sphere of consciousness (the national divide sharpened).
} 


\subsection{Thinking in the Categories of National Values}

In Bauer's view, humans are not only passive observers and recipients of history, but actively participate in its construction. Similarly, they are subject to the effects of culture passed down through generations, while at the same time ardently transforming it. This is the reasoning behind Bauer's argument that individuals are active products of their nation, including its historical defeats and victories, material conditions, and intellectual culture created over the course of centuries. The vital element for the role of the individual in the world is the will. The individual will, which establishes the scale and hierarchy of values, is subject to two types of determination: intellectual and emotional. According to Bauer, humans follow two opposing value systems: a rationalist and a national one:

National evaluation and rationalist evaluation are both rooted in human nature. The former is ultimately based on the fact that the human being, bound to the nation by a causal relationship, is the product of his nation. The latter is based on the fact that the human being is a being that sets itself goals and chooses means, a being that orders itself within the natural and causal context through conscious action. Both forms of evaluation arise from the nature of the human, both are equally ineradicable, both are found in every human being, struggle with each other in every individual. $^{15}$

Bauer captured the fact that the sphere of values is the real subject activity of humans that orients itself towards other people as well as nature. Thus, nature loses its substantiality as something external to humans: instead, it becomes matter continuously in flux according to human needs. In relation to nature, humans are guided by reason - they are progressive and revolutionary. With regards to their fellow humans and under the leverage of national traditions, however, they are governed by emotions and become conservative. ${ }^{16}$ Bauer did not believe that these two value systems often manifested themselves simultaneously. ${ }^{17}$ Essentially, he thought that in the course of human history, the national system of values had been dominant.

\footnotetext{
15 Bauer 1996, p. 127.

16 Przestalski also wrote about this, adding that Oskar Lange produced a similar theory in the 1950s. See Przestalski 1981, p. 213.

17 He referred to the work of Gotthold Lessing as an example of rationalist value judgement and nationally conditioned value judgement interpenetrating and determining one another. In his analysis, Bauer erroneously deduced that Lessing attempted to liberate
} 
In his further observations on the value question, Bauer particularly focused on the national conditionality of judgements and ethics. When individuals evaluate their actions through the prism of the nation, they either subordinate their own system of values to the national interests, or alternatively submit to the complex of values, norms, and judgements produced by a nation. Bauer attached greater importance to the second interpretation, arguing that the evolution of a national culture was strongly affected by tradition. The practical expression of this was a sentimental and declamatory glorification of German bourgeois culture in his writings. ${ }^{18}$ As an aside, Bauer did not inquire into the essence of values, nor did he consider investigating them scientifically. He simply took their existence as a given, claiming they, like the realm of culture in its entirety, were objective and subject to historical change in the course of social evolution.

This led him to another substantial idea, namely that values had a class character. Values promoted at any given moment in the course of historical development are, according to Bauer, synonymous with the values of the dominant social class. The existing social order serves to protect certain national values, and it is simultaneously committed to values that serve to perpetuate the rule of the powerful classes. Bauer accused the ruling classes of demoting national values to a mere tool of class struggle by employing trickery: to defend their interests, they construe any resistance of the oppressed against the existing social order as an assault on the national tradition. Bauer added that value judgement depends on the goals that individual classes have set themselves. In the age of anti-absolutist and anti-feudal struggles, the bourgeoisie aspired to rationality. It assumes a conservative bias, frequently citing the need to defend national values, during the period of high capitalism. The class struggle gives rise to the following: rationalist thinking characterises classes that fight for social and economic liberation, while appeals to national traditions and conservatism typify the ideology of the ruling classes. The development of capitalism produces a new social class, the modern proletariat. Having been excluded

German culture from French cultural influences to restore and preserve the values of his own nation. However, he aptly observed that Lessing's work accommodated the interests of the rising German bourgeoisie, which rejected French court culture without having yet established its own ideology.

18 Bauer was convinced of the superiority of German culture over the cultures of other nations. Mommsen points out that by categorising every new cultural achievement as an achievement of the German nation, Bauer was also hiding national motives behind his humanist and emancipatory deliberations. See Mommsen 1979b, p. 212; compare Mozetič 1987, pp. 225-6 and Hanisch 2011, p. 95. 
from cultural assets for hundreds of years, after all, it emerges free from tradition. In place of the rigid and obsolete, it creates a new ideology. According to the law of historical progress, Bauer argued, national values have to give way to the values of the proletariat. The first reason for this is that the idea of socialism embodies the highest supranational and universal human values. ${ }^{19}$ The second, which deserves particular scrutiny, is that socialist and national ideas are not mutually exclusive, as will be elaborated on later. Without delving too deeply into this, it is important to note that the reality of the multi-national monarchy was very different from Bauer's idealised perception. For the workers of many nations - especially Polish and Czech workers - nationalist and pro-independence rhetoric bore more truth than proletarian internationalism and socialism.

\subsection{Cultural and Natural Community}

Bauer challenged the theory of the nation commonly accepted in contemporary sociology. In particular, he criticised empiricist positions and the naturalist current. The former, in his opinion, were particularly salient in the writings of Italian sociologists. They were also present in Stalin's renowned essay on the subject. Definitions of the nation offered in these texts were based on chronicling common assets such as ancestry, territory, language, customs, morality, law, religion, and the past. In Bauer's view, although these elements were important to various degrees, merely listing such idiosyncrasies revealed little about the essence of the nation. He pointed to the main difficulty that rears its head when this factor theory is applied to living, changing organisms such as the nation. The problem relates to structuralising individual components and the nature of their mutual relationships (those who follow contemporary sociological literature will be aware that this problem remains contested).

The crucial point of Bauer's research was to find a concept that would overcome this problem. For this purpose, he developed a definition of the nation that harked back to the Kantian concept of community, which Bauer borrowed from Max Adler's texts, and Ferdinand Tönnies's understanding of the same term. ${ }^{20}$ Claiming that the 'community' was the original source of

\footnotetext{
19 The Second International turned the notion of socialism as the embodiment of universal values into a dogma.

20 See Adler 1978. In Community and Society, Tönnies introduced the concept of 'community' to denote the nation and the concept of 'society' to denote the state. For this purpose, he distinguished two types of regulation: internal (linked to the emergence of social bonds and based on the community of mindset and fate) and external (which emerges due to the effects of legal norms, customs and language). Tönnies based the concept of
} 
all social relations, ${ }^{21}$ Bauer made it the central concept of his sociological observations. ${ }^{22} \mathrm{He}$ emphasised: "The nation is not a sum of individuals; rather, each individual is the product of the nation; the fact that they are all the product of the same society makes them a community'. ${ }^{23}$ The essence of community is that the individuals who sustain it are tied together by psychological social bonds. Drawing attention to the importance of psychological social bonds for the existence of social structures, Bauer, like Adler before him, accentuated their formal elements. With reference to Adler's category of 'socialised man', he assumed the transcendental existence of social bonds. That is to say, social bonds are not forged as a mere result of interpersonal relationships, but appear only with the a priori socialisation of individual consciousness, which in social life unifies subjects in all their diversity. In this sense, the existence of social bonds involves the ontological, transcendental uniformity of the subject-world. Following Adler's critical theory of consciousness, Bauer defined the societynation as a distinct phenomenon of socialised man. The existence of the nation, he argued, could not be explained with reference to the outward form of human nature or, as conceived of by Rudolf Stammler, by appealing to an external law. Bauer adopted a transcendental interpretation instead. Accordingly, he criticised the individualistic theories, particularly the atomistic model, which defined the society-nation as a collection of individuals linked by a net of

community on the former and that of society on the latter regulation. Pawlak summed up Tönnies's distinction as follows: 'The community is made up of individuals equipped with a natural, spontaneous will (Wesenswille), while a society consists of members who possess a purposeful, rational will (Kürwille). In the community, people are tied together emotionally - their mutual relations are benevolent, harmonious, based on tradition and religion. A community fully engulfs the personality of each member. In society, the basis for co-operation is individual interest, agreement, calculation, public opinion' (our translation) - Pawlak 1979, p. 85. Bauer voiced reservations that he would attribute an alternative meaning to these categories. Nonetheless, his convictions overlapped with those of Tönnies. His differences can be put down to a transcendental interpretation of social bonds. Finally, Bauer did not employ the concept of community consistently. When differentiating between nation and class, for instance, he used the term 'community' to epitomise the nation and the term 'society' to mean social class. In spite of this, he frequently understood the class as a community and its social institutionalisation in the form of trade unions and political parties as society. Compare Mozetič 1987, p. 223. Bauer 1996, p. 111.

To prove the consistency of his theoretical and methodological revelations, he associated this with two categories, although he often used them interchangeably: society and nation. It is worth noting that the two concepts are not synonymous in sociological literature. 
reciprocal relationships. 'The nation', he wrote, 'does not exist by virtue of a formal convention, but is - logically, not historically - anterior to every formal convention. ${ }^{24}$ According to his premise, the introduction of external regulation (language, legal and moral norms) was immaterial in terms of the genesis of the society-nation, since 'external regulation is the form of social collaboration between individuals united by the community'. ${ }^{25}$ Affinity, conversely, emerged because of the internal, a priori socialisation of human nature.

Having established his classification of the nation on a transcendental basis, Bauer then attempted to define it. The result of his analysis was that the nation always represented a unity between the community of nature and the community of culture. The following observations will illustrate (1) the evidence on which Bauer based his definition of the nation, and (2) what the proposed definition means from Bauer's perception.

Beginning his inquiries with the theory of heredity, Bauer criticised not so much the insights of Darwin and Weismann, but the practicability of biological and naturalist theory for investigating social phenomena. In his view, heredity theory sought the origins of the nation in specific organic matter, i.e. in a biological seed passed down from generation to generation (germplasm). Bauer referred to positions based on Darwin and Weismann's theories as 'national materialism'. It was his belief that the positive role of biologism rested on one simple accomplishment. That is, it challenged the legitimacy of spiritualist and idealist theories, which suggested the existence of a mysterious spirit permeating the nation, revealing itself in all activities and forms of consciousness that the nation produces. That aside, he did not believe that 'national materialist' theories had any explanatory value. Moreover, he objected to them because they capitulated to a biological and race-anthropological determinism that he rightly regarded as an early stage of racist theories. ${ }^{26}$ When drawing on the theory of heredity, Bauer modified its scope and range. He did so in opposition to Social Darwinism, but also sought a possible transition to historical materialism within hereditary theory. The hereditary process, in his view, encompassed two mutually dependent processes: (1) the inheritance of physical and intel-

\footnotetext{
24 Bauer 1996, pp. 110-11.

25 Bauer 1996, p. 111.

26 According to these theories, causal relationships have one sole form: if A occurs, then В is its strictly defined consequence. Bauer referred to this causality as 'substantial' or natural. He explained it as follows: although the same processes occur in the natural and human-made worlds, and although phenomena are linked in a chain of cause and effect, different kinds of causality apply in the two spheres: these being natural and social causality respectively (these categories have already been explained).
} 
lectual (biological and socially conditioned) traits, and (2) the acquisition of cultural gains and values. For Bauer, contemporary natural sciences could not really explain in detail the mode of acquiring social traits such as courage, humility, discipline, or loyalty. He argued that these traits were a result of living conditions, lifestyles, education, and social environment. Hence, he suggested that personality traits of successive generations reflected bygone social conditions and modes of production. Investigating the nation as a community of nature required taking into consideration not only its genetic material, but also the transformation of relations of production and exchange.

As Bauer observed, the material conditions for the reproduction of social life already belong to the sphere of social phenomena, which are characterised by an extensive diversity. These conditions define what traits successive generations inherit. Bauer's analysis had enormous implications: he recognised that biological theories could never provide an adequate description of the social prerequisites for human subject activity. Hence, he protested the inclusion of the nation in the biological natural realm of reality. If the nation is conceived as a literal, biological entity, then the national community of nature becomes a community of descent based on blood kinship. Such a community is, at least in its purest form, no more than an abstract concept that never existed in human history. One main tendency of the community of nature is the steadily expanding degree of differentiation. It leads 'an originally unified people' to 'split into different nations. This is a general law: every nation whose cultural community is based exclusively on common descent faces the threat of differentiation. ${ }^{27}$ Clans and tribes can unite to form a nation only on the basis of an identical intellectual culture that provides identity. Bauer was explicit on this: 'A mere community of nature without a community of culture may as a race be of interest to anthropologists, but it does not form a nation. The conditions of the human struggle for existence can also produce the nation via the means of the community of nature, but they must always do so via the means of the community of culture.'. ${ }^{28}$ One can only separate these two types of community in theory. That is why, according to Bauer, the nation will always represent a unity of the community of culture and the community of nature. The belief that they condition each other formed the basis for Bauer's definition of the nation.

His definition was also cultural, entrenched in Herderism and German Romanticism. It attached greater importance to the inheritance of cultural

$27 \quad$ Bauer 1996, p. 39.

28 Bauer 1996, p. 106. 
assets than to the heritage of natural traits. ${ }^{29}$ The heritage of cultural assets, for Bauer, is the most decisive factor for a nation's durability. Consequently, tradition, whose significance Bauer strongly accentuated, encapsulates the idea of the nation. The values passed down through cultural tradition define the national character to a great extent. This process occurs gradually. The first step is childhood and youth, the period in life when humans are the most receptive, yet also the most passive. The second step is the maturing period: the individual rejects certain established standards and helps to introduce new values. When discussing the inheritance of cultural assets, Bauer touched on an important matter: he noticed that certain elements of intellectual culture are eliminated through the process, while new elements are born..$^{30}$

To return to the pre-eminence of the community of culture over the community of nature in Bauer's theory of the nation, it should not be overlooked that this contained three wholly different implications. The first implication is summarised as follows: that which is non-material, intellectual, or spiritual determines what is natural. The second and third implications were politically inclined: the second is best understood as the endeavour to solve class antagonisms by appealing to the concept of a 'culture nation' (Kulturnation), a term still used by the Social Democratic Party of Germany. The third implication was an argument for accepting the hegemonic status of the cultural element. According to Bauer, its impact should set the limits of national sovereignty. The author was fully conscious of the third implication; after all, he intended for a theory of the nation that would solve the nationalities question in the AustroHungarian Empire. His theory was palpable in the principle of national and cultural autonomy for all nations of the empire. It embodied the centrifugal and centralist ambitions of the monarchy, as well as of Austrian Social Democracy, which allied with the monarchy on the nationalities question.

Bauer's cultural theory of the nation was castigated for its abstraction from economic conditions. This was unjustified insofar as Bauer allowed plenty of room for the inclusion of material factors in moulding national conscious-

29 One can find the same cultural approach to the national question in Schlesinger 1950, and in Poland in Chałasiński 1966, Horwitz 1907, Luxemburg 1976, Niedziałkowski 1922, Ossowski 1967, Siwek 1921, Wasilewski 1929 and Znaniecki 1952.

It is difficult to concur with Przestalski's statement that Bauer 'ascribes considerable autonomy and independence of social relations to this idea, assuming that a specific form of social consciousness, once established, becomes permanent, its continued existence secured once and for all ... What is being negated here is the thesis that consciousness is socially determined' (our translation) - Przestalski 1981, p. 217. Bauer's theory implied a diametrically opposed situation. 
ness. Indeed, he suggested that economic transformation, the development of a commodity money economy under feudalism and the development of capitalist production in particular, were the very foundations of nation forming, as were the accompanying changes in the societal structure. He viewed the process of nation forming as a long-lasting historical phenomenon.

Bauer's definition of nationhood provoked a wave of criticism from Marxists. Kautsky, Stalin, Pannekoek and Joseph Strasser, among others, argued against it. ${ }^{31}$ Although I have examined the contents of these polemics in another text, ${ }^{32}$ it is worth offering a succinct analysis of the debate between Bauer and Kautsky, as well as Stalin's denunciation of Bauer's position. In the course of his polemic with Bauer, Kautsky claimed that a community based on a shared historical fate included not all members of society, but only one class, one social layer, one municipality, one guild, one political party, or one state. He directed his criticism against the concept of the nation as a community of character, pointing to the empirical diversity of individual character traits. In view of the language difficulties in the multi-ethnic state, he identified language as a national principle and designated it as a nation-forming component. Bauer wholly rejected this, responding that Kautsky had not understood his concept of a community of fate: after all, Bauer argued, it rested on transcendental foundations. Moreover, Kautsky had mistakenly equated common with equal fate. To recognise the a priori character of social bonds meant to admit to their primary existence in relation to their historical forms in empirical reality. Language was not a determinant of community because it was a cultural product and instrument of communication, i.e. the means of a secondary order. It was not possible to elevate it to a national principle, as examples of divided nations that shared the same language were historically verifiable. The same goes for nations that had adopted the language of an occupying power or of the territory they inhabited. According to Bauer, language conflicts served as a pretext to conceal economic and class antagonisms. Stalin's critique, by contrast, allied heavily with the factor theory Bauer rejected. Stalin interpreted the nation as a mosaic of traits such as language, territory, economic life and culture, and if one of these assets was missing, one could not speak of a nation. What is more, he accused Bauer of omitting these factors in his analyses. The principle difference between Bauer's and Stalin's positions was that Bauer classified certain traits, for example national character and culture, as imperative for the essence of the nation. Arguably, Bauer's intention was entirely defensible. In formulat-

31 See Kautsky 2009, Pannekoek 1912, Stalin 1913 and Strasser 1912.

32 See Czerwińska 1991, pp. 326-8. 
ing a broad notion of the national character, he demonstrated that it permeated through all forms of human activity determined by socio-economic living conditions. His model contained all the elements that Stalin mentioned, but also additional prerequisites for nation forming. Bauer was perceptive enough to stress that features such as national character, national consciousness, and culture were the specific traits of a nation that determined whether it would endure.

\subsection{The Determinants of Modern Nation-Forming}

The concept of the nation served Bauer to interpret the history of contemporary European nations. Using the example of the German nation to conduct his analysis of the premises of nation forming, he investigated the processes that lead to the emergence of conscious national communities. Furthermore, he studied class contradictions that limited the capacity of these communities and ways to overcome them. Bauer examined three aspects of the nation-forming process: cultural, economic and class-related. Seen from this perspective, the analysis of a nation's history becomes an analysis of the trajectory in which a socio-economic construct evolves. The transition from a 'lower' to a 'higher' stage of the nation is thus conceived of as a general law of historical evolution and criterion of progress.

According to Bauer, it is possible to distinguish between two stages in the history of a nation. The first is bound to the emergence of tribal organisations and nomadic communities. These communities are self-contained political entities whose members form a homogeneous unity through blood bonds, social relations based on common ownership of the means of production, customs inherited from their ancestors, moral values and language. In this pure, primordial form of the nation, social life is characterised by the participation of all members in shaping the politics, law, and morality of their community - i.e. they all have an equal say in the creation of an intellectual culture in the broadest sense. Bauer put forward an interesting hypothesis: according to him, the communities of ancient Greeks, Romans and Celts that emerged in the primitive epoch were based on a different type of association from those that emerged in class societies. As agriculture and sedentary lifestyles replaced nomadic ways and Germanic tribes mixed with the populations of the conquered lands (Celts and Slavs), the original clan community of the Germanic people fell apart. At the end of this process, their community of culture disappeared. At the same time, the end of this process marked a break in the nation's history. Although Bauer referred to this elemental culture as primitive, he did not undervalue its importance for the German nation-forming process. He even reasoned that German community collapsed due to the division of labour and property the 
moment social relations based on opposed economic interests took shape. The genesis of modern nation forming coincides with class differentiation and the emergence of private ownership of the means of production. The rise of the ruling classes marks the beginning of the second stage in a nation's history - a stage that continues to the present day.

Compared to the earlier form of the nation, the new feudal nation was fundamentally different inasmuch as it had a class structure. The feudal nation was a community of the ruling classes, the knighthood and aristocracy. The integration process in the feudal era merely unified landowners into a community of culture: 'The unifying moment that linked the nation together, however, was no longer that of a common culture handed down from a common ancestral people, but that of a new community of culture'.33 From this, Bauer concluded that the German nation in the age of feudalism was not a continuation of the Germanic clan nation. All high intellectual culture - a product of knighthood was based on the French model. Moreover, Bauer stressed that the preservation of the nation in this form was only possible due to the exploitation of the peasantry. In the middle ages, the peasants were the largest group among the 'tenants of the nation' (Hintersassen der Nation) - i.e. popular masses excluded from creating and receiving cultural assets and condemned to form isolated local communities.

The sharp divide that had separated the propertied classes from the popular masses lessened with the inception of the capitalist mode of production and emergence of a modern political system, the bourgeois nation state. As Bauer observed, commodity economy and the political changes initiated by the bourgeois revolutions played an enormous function in the transition from feudalism to capitalism. In these revolutions, the national idea was an element of integration for the nation. Here, Bauer agreed with Kautsky: the capitalist mode of production and exchange and the changes in the economic apparatus of society were the factors of integration that assembled the nation as a fully conscious, united entity. The confluence of the nation occurred not least on account of the socio-political changes heralded by the development of modern capitalism, but it was also due to the establishment of an education system, standardisation of the language, and political gains such as universal suffrage, parliamentary democracy, and freedom of assembly and association. Another uncontested gain of capitalism was its tendency to overwhelm impediments to supranational integration. However, in the era of modern capitalism, the masses are, according to Bauer, part of the nation only to 
the extent that they submit to the framework set by the culture of the propertied classes. ${ }^{34}$ For Bauer, the most important phenomenon engendered by the development of capitalism was the emergence of an internationally organised labour movement. This movement anticipated the political emancipation of the proletariat by augmenting its position to the national class and hegemon. To what degree the working class becomes the leading force in the process of national integration depends upon the degree to which its class priorities intersect with the interests of the nation. The process of integration will be finalised in a proletarian state in which culture is accessible to all.

In his account, which also delineated the communities of culture in more detail, Bauer also illustrated the history of the nation. During the first stage, there is a clan community of culture, the clan nation. During the second, the feudal nation unites a narrowly confined elite of landowners into a community of culture. In the capitalist nation - the third stage - economic and political ruling classes define the essence of the community of culture. This community, however, exhibits a stronger tendency to national affinity based on education and politics than the fragmented local communities of the feudal epoch. The final stage is the solidaristic community of the future, the socialist nation. Unlike all earlier communities, it is based on the equal and universal participation of all citizens in national culture. Bauer did not foresee any potential processes of disintegration in socialist societies.

Bauer's analysis also contained a differentiation of nations rooted in the Hegelian tradition popularised by Engels, distinguishing between historic and non-historic nations. ${ }^{35}$ The introduction of these categories remained associ-

34 According to Bauer, the confines of the bourgeois community of culture are transparent: it encompasses the court nobles, landowners, high officials, the prosperous bourgeoisie, and the newly emerged independent urban professions. See Bauer 1996, p. 69.

Engels justified the differentiation between historic and non-historic nations by citing the difference between civilisation and barbarism. He equated civilisation with the development of industry, capitalism, and the rise of the bourgeoisie, while identifying barbarism with economic backwardness, feudalism, and peasant culture. See Engels 1977. The theory of non-historic nations was also present in Ferdinand Lasalle's work: he remarked that the French had a justified historical and cultural mission with regards to the Algerians, as the British had towards India. See Bernstein 1892, p. 30. Butterwegge stated: 'Bauer's adopted differentiation between "non-historical" and historical or cultural nations, which corresponded with his Greater Germanism and implied a German-Austrian cultural mission with respect to the Slavic peoples, was ambiguous to say the least. Indeed, his book was cited by the German Social Democratic leadership to justify its approval of war credits for World War I' (our translation) - Butterwegge 1981, p. 131. 
ated with the question of the so-called political nation, i.e. a national community contained in its own state (among Austromarxists, Karl Renner stressed the political aspect of nations). ${ }^{36}$ Bauer described those that were already on the cusp of forming capitalist relations of production and displayed a fully developed social structure, especially its own propertied class, as historical nations. For example, Germany, Italy, Poland and Hungary all constituted historical nations because they lacked their own native upper classes; Bauer viewed Czechia, Slovakia, Serbia and Romania as still being non-historical nations in the nineteenth century. As Marx had done in The Communist Manifesto, Bauer argued that the late nineteenth century had seen a change in circumstances: capitalism had created the conditions for the development of national cultures, leading to a revival of nations 'without history'.

To further demonstrate the process of rebirth of non-historical nations, Bauer analysed the last two hundred years of Czechia's development. He cited five factors which contributed to the emergence of a mature Czech nation: (1) The development of a domestic ruling class accompanied the development of capitalism and weakened the influence of the German bourgeoisie. Bauer noted that the 1848 bourgeois revolution in Austria had also been a national revolution. National revolutions, he concluded, were a driving force in the genesis of nations. The leading role in the process of national integration fell to the Czech bourgeoisie. (2) The Czech bourgeoisie adopted the liberal and humanist slogans of the French enlightenment. (3) The development of the national education system and language allowed broad popular layers to participate in national culture. (4) The proletariat became increasingly class-conscious. (5) In the course of struggle against the German ruling class, the intelligentsia became politically conscious and increasingly solidaristic with other classes. Chiefly, Bauer did not see the intelligentsia as an intrinsic agent of the national idea. Rather, he believed that it did not possess the necessary material and political strength to accomplish the project of national unification. Due to these factors, the Czech people, who had previously lacked any political or administrative tradition for hundreds of years, rose up and fortified themselves as a historic nation in possession of a nation state.

36 Renner 1964, p. 11. It has to be emphasised that the terms 'nation' and 'nationality' are rather diffuse in Bauer's The Nationalities Question. Particularly in relation to the opposition between community and society that Bauer had described when defining the essence of the nation, it is fair to say that he did not apply the term 'nation' consistently to the 'stately nation' ('historical nation'). Moreover, he used 'nationality' to denote two different things: (1) belonging to a nation, and (2) an ethno-cultural community that lacks political rights and constitutional guarantees ('non-historical nation'). 
With final regards to the historical forms of the nation and its prerequisites, it is worth mentioning that Bauer, in his historiosophical position on the rebirth of peoples, once again referred to the role of culture in the process of nation forming. He alluded to the specific cultural mission of historic nations in relation to non-historical nations. ${ }^{37}$ As Bębenek demonstrates, this notion originated in Hegelian historiosophy. ${ }^{38}$

\subsection{The Nation as a Real Community of Culture in a Future State}

In the course of his reconstruction, Bauer distinguished three basic types of national community of culture (while identifying the four different types of nation):(1) the clan community; (2) the antagonistic class society; (3) the solidaristic community of the future, i.e. the socialist society. Bauer's classifications had an unambiguously evaluative character: his criterion was access to national culture and possibilities of participation. The choice of this decisive factor logically resulted from the author's overall conception.

According to the criteria Bauer had established, the clan order, in which all members were carriers of society's material and intellectual culture, represented an exemplary form of the nation. It lost this form in the feudal age, as class contradictions intensified. The popular masses were excluded from the national community, and any possibility of participating in the political and cultural life of the nation was confiscated from them. ${ }^{39}$ According to Bauer, the process of integration in the feudal and early capitalist eras only unified a narrow social group into a community of culture, namely the propertied classes. The cultural assets only became the property of the whole nation as the capitalist system evolved. Yet in Bauer's view, this system also excluded the possibility of fully realising the nation. It erected material barriers that prevented the nation's various classes and social layers from equally participating in its gains. Bauer argued that it would only become a nation again under a socialist constitution: in the future state, the socialisation of the means of production, social character of labour, and final abolition of inequality and privileges would facilitate participation in culture. Without dissecting Bauer's views on these matters - after all, this would also necessitate investigating Marx's rel-

37 Bauer was particularly concerned with the cultural mission of the German nation towards the Slavic peoples. See also Butterwegge 1990, p. 131 and Hanisch 2011, p. 98.

$38 \quad$ See Bębenek 1987, p. 35 .

39 It is certainly remarkable that Bauer's analysis bypassed slaveholder society. He thought of it as irrelevant and not clearly distinguishable in the evolution of the nation. This view can be attributed to the fact that slavery had never been dominant among the nations that he analysed. 
evant theories - the aforementioned statements contained three portentous insights: Firstly, the participation of the masses in culture helps to integrate the masses into the nation. Secondly, whether the nation prevails depends on whether the liberated classes cultivate the assets of the old culture. Thirdly, the cultural education of the masses will be as inseparable from the socialist order as the public appropriation of the means of production. Bauer thought that the socialisation of labour was the most important element in the transformation process. The Polish philosopher and cultural critic Stanisław Brzozowski had similar ideas: a nation could only become a self-contained cultural community if it first became a community of labour. The liberation from reified labour, an essential factor in satisfying intellectual needs and fostering the development of culture, would lead to the realisation of a complete, real nation.

Based on this, Bauer established that the proletariat was the executer of the national idea and the driving force of progress in the realm of culture. He was deeply convinced that only the rule of the working class would create the conditions for a nation in the full sense of the term, as it would strengthen the development towards an intellectually unified civilisation. Bauer believed that the task of the modern proletariat was to build a socialist state and conquer national culture for the benefit of the entire nation. Bauer's initial sentiments were: 'The international struggle is a means that we must use to realise our national ideal' ${ }^{40}$ He therefore disagreed with Luxemburg and Lenin, who argued that the national movement was an obstacle for the class struggle. They feared that nationalism would spread if the proletariat pursued crossclass objectives. In response, Bauer suggested that the consolidation of proletarian social consciousness had a class character and a simultaneous national essence.

Viewed with the benefit of historical hindsight, the veracity of his further statements is questionable. Bauer claimed that the position of the proletariat within the class hierarchy had far-reaching implications for its position on the nationalities question. The proletariat, he proposed, would only support the national idea if national aspirations for independence coincided with the struggle for class liberation. Bauer frequently emphasised the class character of the national struggle for sovereignty, pointing to the integral connection between class divisions and divisions within the nation. This belief was widely held in the Second International. If the proletariat succeeded in abolishing class antagonisms, this would also end national oppression. This was the only convergence of Bauer's views with the official position of the Second International. 
Bauer staunchly focused on the interpenetration of different cultures and consequent emergence of an international culture. ${ }^{41}$ Unlike Kautsky, though, he did not believe that increasingly fluid cultural boundaries would eliminate distinct national characteristics. According to the Marxian view, the nation would lose its value with the victory of socialism and realisation of a classless society. Numerous socialists, including Luxemburg and Jean Guesde, concluded that the concept of the nation was a bourgeois myth. For many, the socialist idea also contained what Bauer referred to as a 'naive cosmopolitanism' (Bauer's term) inherited from humanist enlightenment philosophy. Bauer believed differently: for him, proletarian internationalism was not synonymous with cosmopolitanism. In his mind, socialist ideology had to rest upon the foundations of every respective nation's cultural traditions. In defiance of common formulas, he declared that socialism would not only preserve national identity, but it would even strengthen and develop it. ${ }^{42}$

All of Bauer's observations had a corresponding point of reference: the realm of culture. On this basis, he attempted to explain the development of the national character, the genesis and determination of national consciousness, and the role of value judgement in the process of nation forming. What is more, he aspired to distinguish the objective bonds which tied individuals to a nation and examine restrictions which interfered with the integration of the whole nation. Bauer's belief that the participation of all citizens in national culture was the fundamental condition for the existence of a nation in the full sense still informs contemporary theories on the nationalities question. ${ }^{43}$

Bauer's undeniable merit was his challenge to many stereotypical concepts of the nation to which socialists adhered during the Second International period. Equally valuable was the simple truth that every nation possesses an intrinsic value and has its own unique dynamics of development. Bauer's belief in the longevity and identity of nations based on culture is still viable in European consciousness.

\footnotetext{
41 This was directly opposed to Lenin's position. Lenin opposed national culture as bourgeois nationalism and advocated for a consistently democratic and socialist international culture. See Lenin 1963, pp. 246-7.

42 Kołakowski, Mozetič, Kulemann, and many other Austrian authors have also mentioned this. See Kołakowski 2005, p. 298; Mozetič 1987, p. 225; Kulemann 1979, p. 127.

43 It is worth mentioning the following Polish scientists in this regard: Cackowski 1974; KozyrKowalski 1974; Wiatr 1973.
} 
As we have seen in the previous chapter, Otto Bauer placed great emphasis on the integral link between the process of nation forming and the cultural realm in the broadest sense. The cultural theory of the nation focused on the role and value of a society's intellectual culture and tradition. It was based on a strong belief that class antagonisms and social contradictions are reduced when a nation matures, and are entirely abolished under socialism when broad social layers are able to participate in national culture. These elements provided the foundation for Bauer's programme to solve the nationalities question under the Habsburg monarchy. It is entirely justified to claim that until 1918, all of Bauer's observations on the national problem were subordinated to the political aims of Social Democracy, i.e. they served to resolve the ferocious conflicts between the nations incorporated into Austria-Hungary. From the 1880s onwards, they manifested themselves more sharply.

National conflicts were an element inseparable from political life under the Habsburg monarchy since its inception, even if in the times of centralist absolutism, the causes were different from those in the era of constitutional federalism. During the first period, the so-called Hungarian question - i.e. the struggle surrounding Hungarian independence - was prevalent. The second revolved around the decentralist and separatist aspirations of Poles, Slovaks, Italians, Croats and South Slavs. To be sure, the lands ruled by the monarchy were granted autonomy in the 1861 constitution: tasks of self-administration were delegated to local parliaments. At the same time, the position of the aristocracy and wealthy bourgeoisie, which was overwhelmingly of German descent, was strengthened in their respective territories. Contrary to the expectations entertained by liberal politicians in the empire, the introduction of dualism in 1867 - i.e. the establishment of Austria-Hungary - did not end national conflicts. Rather, it only strengthened the central powers in the two divided states. The ruling nations tried to keep the less developed nations economically and politically subordinated, and - understandably - encountered resistance from the latter. National struggles sharpened particularly in the 1890 .

A closer look at the fundamental issues underlying these conflicts reveals that socio-economic and political reasons were prevalent. However, one should not minimise psychological and emotional factors either. Let us remember that at the turn of the nineteenth and twentieth centuries, Austria-Hungary made up a territory of 260,242 square miles and comprised a population of $5^{1}$ million - among them, two million Germans, 10 million Hungarians, nine million Czechs and Slovaks, seven million Croats and Slovenes, six million Poles, 
three million Ukrainians, and one million Italians. ${ }^{44}$ It was a state that comprised territories of varying levels of economic development. Industrialisation was accomplished particularly in Lower Austria, Styria, Silesia, Bohemia and Moravia. In the other parts of the country, especially Hungary and Galicia, industrial development was low - above all, large-scale land ownership was an impending factor, taking up some 45 percent of the land surface. As monopolies formed, small and medium-sized businesses could not compete with big German enterprises. These countries provided a basis for raw materials and a supply of cheap labour. Particularly in Bohemia, Moravia and Galicia, where a strong bourgeoisie emerged in the 1880 s, the dependency on German capital was viewed not only from an economic, but also from a national perspective. In all countries ruled by the crown, increasing exploitation went hand in hand with political subjugation: an anti-democratic system of government whose political, military and administrative posts were staffed mainly by Germans, alongside discrimination in education and against national languages and cultures. Another source of conflict between the peoples was socio-economic differences between ruling and subordinated countries. They affected the working class first and foremost - the relatively good conditions enjoyed by Czech workers employed in German-speaking territories were an exception to the rule. The German-Austrian workers formed the 'labour aristocracy' of the empire which, incidentally, significantly influenced the national policies of the SDAP leadership. Their income was a fifth higher than the income of workers in the other countries, they were better educated, and they had better developed organisational structures in the trade unions. ${ }^{45}$ Furthermore, they were very receptive to petty-bourgeois ideology, part of which was German nationalism. Opposing economic interests, competition between German workers and those of other nationalities, and rampant nationalism made an emergence of class consciousness and a united struggle of the Austro-Hungarian proletariat impossible; the effect was that differences within the class concurred with national differences. At the end of the nineteenth century, anti-Semitism and conflicts between competing local nationalisms, skilfully fostered by the Christian Social Party, threatened the peace between the peoples of the monarchy.

There is much to suggest that national conflicts were indeed among the main reasons for the longstanding division within the Austrian workers' party from 1866-89. Both factions - the moderates under the leadership of Heinrich

\footnotetext{
44 Kreisler 1970. Rauscher depicts the roots of national conflicts under the Habsburg monarchy in an interesting fashion - see Rauscher 1995, pp. 45-6. 
Oberwinder and the radicals under Andreas Scheu - were clear that the socioeconomic and political interest of the working class required energetic consolidating action. As a condition for the success of such action, however, a position had to be formulated to finally reconcile national interests and resolve issues concerning nationalism and the working class. This question also remained fundamental and acute for the Social-Democratic movement that united in Hainfeld. Notably, this movement claimed to be Marxist from its inception hence, the Austrian socialists consistently attempted to base their solution to the national question on socialist theory. Under Austrian conditions, this attempt was bound to fail. This requires some explanation.

One question in particular springs to mind: did the classical Marxist texts and the positions of the Second International contain any theoretical solutions in the interest of the working class that could be practically implemented in a multi-national state?

For Marx and Engels, the problem of specifically national working-class interests did not really exist. ${ }^{46}$ When they were active, nationalism was not a significant factor of political life, and they did not pay much attention to it. ${ }^{47}$ They located the source of national conflict in the class character of the bourgeois state. In their view, free competition - i.e. free trade, the emergence of a world economy, and standardisation of the forms of production - would level differences and antagonisms between the peoples during the period of capitalist development. These contradictions would then be abolished entirely with the unification of the proletariat and its seizure of power. Marx and Engels deemed the socialist revolution the real means for the emancipation of the working class and oppressed nations. To be precise, the classical Marxist texts viewed the solution to the national question as depending upon the solution to the social question. They regarded national struggles not as an independent factor of history, but as an integral component of the class struggle. Let us note, however, that Marx's - but particularly Engels's - conception of the national problem led them to champion nations that they believed were carriers of historical progress. For them, large economic and political organisms were progressive. ${ }^{48}$ Because they believed that these organisms were the focus of revolutionary energy, they projected their desire for socialist revolution upon them and expected them to provide the catalyst. Their thesis that the world revolution was an objective consequence of historical development and would

\footnotetext{
46 Helmut Konrad offers more details about the classical Marxists and the national question in Konrad 1976, pp. 6-17.

47 Compare Leichter 1976, p. 78.

48 See Konrad 1977, p. 195.
} 
unite all of human civilisation was irreconcilable with the trend in establishing small independent nation states. ${ }^{49}$

It should come as no surprise, then, that Marx and Engels only took a marginal interest in the problems of the Habsburg state. ${ }^{50}$ In two articles, ${ }^{51}$ Engels took up an ambiguous position on the national struggles in Austria. In his 1848 article, 'Der Anfang der Endes in Österreich' ('The Beginning of the End in Austria'), ${ }^{52}$ he described the monarchy as a bulwark of reaction and national oppression, predicting its imminent fall due to the oppressed nations' growing hatred of their German tyrant. A year later in Democratic Pan-Slavism, ${ }^{53}$ he denied so-called non-historical nations the right to exist as political entities, claiming that they lacked the economic, geographic, historical, and political conditions for an independent political existence. ${ }^{54}$ This position could be interpreted as Engels's approval of the subjugation of less developed nations and condemnation of their emancipatory ambitions.

Marx and Engels's conception of the national question determined the views of Second International theorists. Their leaders - including Karl Kautsky, Jules Guesde and Rosa Luxemburg - feared that highlighting the national question would divert attention away from class antagonisms. Like the classical Marxists, they assumed that the national question would inevitably disappear once the social question had been solved, and that socialist revolution would decide this in the near future. Many Second International activists disregarded progressive aspects of the emergent national identities, and many had

49 'Naturally, in full accordance with the Victorian stereotype, civilisation was identified with Western civilisation, whose main pillars were the United States and the "advanced countries" of Europe' - Walicki 1995, p. 155.

$5^{0}$ In 1860, Marx regarded Austria as a dam against the flood of Russian imperialism. He wrote: 'The sole factor that has justified Austria's existence as a state since the middle of the 18th century, [has been] its resistance to Russian progress in the East - a helpless, inconsistent, cowardly but tough resistance' - Marx 1982, p. 131. Apart from Konrad 1976, pp. 9-14, Hanisch explains the attitude of the classical Marxists toward the nationalities question as follows: 'From the 1840 os onward, Marx and Engels were convinced that the monarchy had to be smashed. The "great nations" that lived in the territories of the Habsburg empire - the Poles, the Hungarians, the Italians - had to constitute themselves as independent republics' (our translation) - Hanisch 1978b, p. 339.

$5^{1} \quad$ Helmut Konrad cites these in Konrad 1976, pp. 9-11.

52 Engels 1975, pp. 530-6.

53 See Engels 1977, pp. 362-78.

54 According to Konrad, Engels's negative view of the Czech and Yugoslavian positions during the 1848 revolution led to his change of mind - he went on to refer to them as counter-revolutionary. 
no idea how to link the idea of internationalism with the principle of national self-determination. ${ }^{55}$ For some Social Democrats, the sheer link between the national principle and the notion of statehood was incomprehensible. Not infrequently, they assumed that historical development would lead to the 'absorption' of smaller nations by larger ones and stressed the significance of assimilation processes - Rosa Luxemburg, for instance, attempted to prove the emergence of supra-national states. Only Lenin warned the leaders of the International that the development of capitalism would awaken the national consciousness of all classes and unite them in their ambition to found nation states. However, his warnings were dismissed.

The positions put forward by the classical Marxists and their successors in the Second International were not particularly helpful for the Austrian Social Democrats for solving the tense relations between the Austro-Hungarian nations. The political situation demanded a programme for present circumstances, and socialism still seemed a long way off in the late nineteenth century. From its inception, the Austrian Social-Democratic movement aimed to create a unified organisation that represented the interests of the whole Austro-Hungarian working class and maintained this unity. Hence, the formulation of a pragmatic national programme was fundamental to the movement's existence and effectiveness. Because socialist theory did not offer the Austromarxists any models to follow, they considered it their task to deal with the so-called Austrian problem on their own. Indeed, Social-Democratic circles strictly speaking, Renner and Bauer - proposed the most interesting solutions to Austria-Hungary's national question in the early twentieth century. For our purposes, Bauer's theory and its consequences for the policies of the SDAP is the key issue. Given that it grew out of the Social-Democratic movements' political practice and, in turn, co-determined this practice, it seems appropriate to preface our detailed assessment with an outline of the national question in the politics of the SDAP.

\subsection{Social Democracy and the National Question}

Authors such as Mommsen, Konrad, Leser, Kulemann and Rauscher all offer thorough accounts of this question. ${ }^{56}$ Hence, it appears unnecessary to write the history of the national question in the policies of the SDAP anew - even more so because the main focus of this sub-chapter is not the national ques-

\footnotetext{
55 Compare Mommsen 1963, p. 202.

56 See Mommsen 1963 and 1979b; Konrad 1976 and 1977; Leser 1968; Kulemann 1979; and Rauscher 1995 .
} 
tion as such, but rather Bauer's approach to it. Our reconstruction will therefore refer to the aforementioned researchers' key conclusions and will be limited to a brief exposition of the Social Democrats' stance. Embroiled as they were in ideological and tactical difficulties, the Social Democrats had not yet taken up a unified position on the national question in the 1860 os-7os. ${ }^{57}$ Documents from the first congresses of the workers' organisations testify to the conflict of opinions. ${ }^{58}$ Likewise, during the period of unification, the Social Democrats were in doubt as to whether they should simply dismiss the national question as a bourgeois chimera and instead campaign for internationalism, or else seek a solution within the existing constitutional framework. The founder of the movement, Victor Adler, was aware of this dilemma. He resisted any debate on the national question in the party as best he could, wary that it might lead to a split in the labour movement. ${ }^{59}$ Adler agreed with Kautsky that the national question could be reduced to a language problem and therefore had to be transferred from the economic and political onto a cultural terrain. Adler underestimated the underlying socio-economic and political reasons for national conflicts. Nor did he recognise the degree of tensions that existed between workers of different nationalities. In the programme of the unifying Hainfeld congress, the Social Democrats consequently argued for maintaining the status quo of the monarchy - a policy that Adler and Kautsky had authored. On Adler's inference, there was conspicuous silence around the national question, which had been bypassed in favour of a strong focus on the struggle for universal suffrage. The resolution proclaimed at congress defined the party as international, yet did not define internationalism more closely. The party

57 The moderates advocated a compromise with the liberal and national parties, while the radicals aimed to maintain independent political action and internationalism.

$5^{8}$ The Manifesto to the Working People of Austria, which had been formulated by the fifth Vienna workers' congress on 10 May 1868, called upon the solidarity of workers of all Austro-Hungarian nations and assured them that the time of national divisions was over. The April 1874 party congress in Neudörfl adopted a diametrically opposite position: the resolution approved of separatist national organisations and adopted the right of nations to self-determination. The programme adopted at the congress in Wiener Neustadt (1315 August 1876), conversely, was a backward step when compared to the progressive parts of the 1874 programme: it attempted to unite the workers around the slogan, 'the workers of Austria fight, but they do so within the framework of the existing constitution' - see Berchtold 1967, p. 199. The 'programmatic resolution' of 1877, which contained a common position of all national organisations on universal suffrage, represented a compromise of sorts. For more on the programmes mentioned here and the national programme of Bern, compare Kulemann 1979, pp. 120-6. 
settled for stating that 'The Social Democratic party of Austria is an international party. It condemns the privileges of nations just as much as it condemns the privileges of birth, property and descent, and it declares that the struggle against exploitation must be just as international as exploitation itself'. ${ }^{60}$ It was decided to solve the national question through a formally conceived principle at a forthcoming party congress. Indeed, few Social-Democratic politicians at the time believed in the necessity of equal rights between nations. They took the claims contained in the congress programme, according to which absolute impoverishment would soon affect the workers and middle classes of all Austro-Hungarian nations to the same extent, at face value. This situation, they thought, would lead to greater international solidarity among workers, and to workers and the petty bourgeoisie rejecting the nationalist mindset. ${ }^{61}$ The party leadership attempted to downplay the fact that nationalism had long infiltrated the ranks of these social groups and become a general social problem. By then, it was playing an ever-greater role in the politics of the state.

The unity of the SDAP brought forth by the Hainfeld programme had a formal rather than programmatic character. It never took shape in reality. Austrian Social Democracy - which was principally German - drew on the blueprints of German Social Democracy. It bypassed the traditions of the Czech SocialDemocratic movement and it did not incorporate the experience of SocialDemocratic organisations in Bukovina or Eastern Galicia, which had built on progressive peasant movements. Only during the period of consolidation did the national centres refrain from infringing on the leading role of Austrian Germans in the labour movement. The party-internal process of nationalisation involving the Poles, Czechs, South Slavs, Italians and Ukrainians was eating away at the SDAP from its inception. Separatist ambitions were particularly strong in the Czech fraction. ${ }^{62}$ As early as 1878 , the Czech socialists founded the Czech Social Democratic Workers' Party with reference to the national principle (it obtained full independence on 27 December 1893). Thus, they opened the door for more and more intense quarrels within the party. The Czechs started the process of national federalisation: their resolution on a federal party structure was passed at the sixth congress of the SDAP in $1897 .^{63}$ The federal

\footnotetext{
6o Berchtold 1967, p. 138.

61 See Konrad 1976, p. 48.

62 Berchtold 1967, p. 138.

63 By act of this resolution, the Austrians, Germans, Czechs, Poles, Slovenes and Russian sections of the party became independent national political organisations. Coordination of political activity was to be secured by a common governing body with headquarters in Vienna, which consisted of delegates from the individual national administrations,
} 
division did not just weaken the workers' movement of the monarchy; it also led to tense relationships between the Slavic parties and the German-Austrian party, with the latter attempting to preserve its privileged position. Suffice it to say, this state of affairs was not beneficial to resolving the national question. While the parties pushed it into the background, it became manifest in the trade-union movement, despite the fact that the unions were organised according to trades rather than the national principle. ${ }^{64}$ Subsequent congresses of the Second International in Amsterdam (1904), Stuttgart (1907) and Copenhagen (1910) sided with the SDAP leadership in defending centralism in the labour movement. Regardless, the disintegration process in the trade unions deepened. ${ }^{65}$

Fearing that national quarrels might erupt into the open and consequently lead to a terminal breakdown of already weak organisational structures, the SDAP leadership made the last attempt in the history of the monarchy to draft a complex national programme. ${ }^{66}$ This took place at the congress in Bern from 24-29 September 1899. The SDAP leadership and the Slovenian socialists presented two drafts to delegates. The leadership proposed to grant territorial autonomy, but preserve a centralised state, whereas the Slovenian draft demanded cultural autonomy according to the territorial principle. ${ }^{67}$ The adopted programme reconciled both positions in that it conceded national and cultural autonomy according to the territorial principle, yet within the framework of a federal state. In fact, the decision to adopt this principle was synonymous with sacrificing the right of nations to self-determination to preserve unity and the inviolability of imperial borders. The resolution did not define the authority of local parliaments and state council more closely, and it was difficult to conclude

joint representation in the state council, and biannual congresses. See SDAP 1897, p. 7; Wasilewski 1907, p. 71.

64 At the 1896 trade union congress, the Czechs demanded an independent secretariat with headquarters in Prague. Although their demand was rejected at the time, national trade unions were operating in Czechia and Moravia as early as 1906. Compare Mommsen 1963, p. 396.

65 Compare Zimmermann 1976, p. 373 .

66 It is discussed in detail in Konrad 1977, pp. 198-200.

67 See Berchtold 1967, p. 145; SDAP 1899, p. 75; and Kelles-Krauz 1903, p. 276. According to Rauscher, "The demand to replace the old crown lands with nationally demarcated, autonomous administrative units and transform Austria into a democratic federative state of nationalities was not new. Nor was the rejection of an official language. The concept of ethnic federalism originated from the time of the $1848-9$ revolution. Moreover, this decidedly moderate political programme meant that Austrian Social Democracy was affirmative of the imperial concept' (our translation) - Rauscher 1995 pp. 46-7. 
from it where the limits of federalism ended and central authority began. ${ }^{68}$ It was assumed that the working class, which was numerically the strongest and enjoyed universal suffrage, would automatically secure the decisive vote in the administrative bodies. The electoral system at the time, which unambiguously privileged the propertied classes, made politics in the interests of the working class impossible from the outset. The programme envisioned a modern bourgeois state based on democratic foundations. Commenting on it, Kulemann rightly notes that it misconceived the link between the national question and the struggle for socialism. ${ }^{69}$ It is easy to explain why that was the case: as mentioned earlier, many Social Democrats failed to acknowledge progressive aspects of national liberation struggles. Therefore, they did not establish a link between national and social revolutions. Moreover, the project of national and cultural autonomy did not imply that fully independent centres of state power would be established. Rather, the intention was to appoint national organs of self-administration with tasks within the spheres of culture and education. Hence, workers' struggles in the respective countries were understood not as attempts to seize political power, but as struggles for access to the cultural sphere against the national bourgeoisie. Mommsen writes: 'This national consciousness was in essence apolitical, not state-oriented. ${ }^{70}$ The situation was, as it were, a closed circle: Austria-Hungary was a patchwork of many nations held together by the emperor, imperial court, state power and army. Given this state of affairs, real bonds to link peoples that did not identify with the state could only be created at a cultural level. History proved that this was too weak a factor in the face of Austrian realities to preserve cultural ties through the state or save the socialist movement from splitting.

Neither the two drafts introduced in Bern nor the suggested solution became reality. Meanwhile, the Slavic peoples of Austria far from relinquished their struggle for equal rights and separation. Contemporary political events, such as the Russian revolution of 1905 and the annexation of Bosnia and Herzegovina, only aggravated the situation. The Czechs refused to give up their efforts for equal language rights in public offices, schools for national minorities, and the right to appoint their own representatives in the state council. ${ }^{71}$ They did

\footnotetext{
68 See Mommsen 1963, p. 107.
}

69 See Kulemann 1979, p. 124. The Polish and Ukrainian socialists, who regarded the suggested solution as a regression towards positions predating the Hainfeld period, opposed the Bern programme.

$70 \quad$ Mommsen 1963, p. 317.

71 In 1905, Czech and German-Austrian Social Democrats stood separately for state council elections for the first time. 
so despite the fact that their separatist aspirations were condemned at the 1910 congress of the Second International in Copenhagen. The liquidation of the common party in 1911, then, only officially confirmed the split between regional organisations that had long been a fait accompli. Already, in 1905, the trade unions had been decentralised into national departments. Victor Adler's grand achievement, the unification of the Austrian workers' movement, fell apart even though this time, unlike in the Hainfeld period, the Social Democrats had a theoretical understanding of the national question, which was essentially contained in the work of Renner and Bauer. Their studies offered concrete in Renner's case, no less than detailed ${ }^{72}$ - reform programmes for the constitutional foundations of the state; thus, national conflicts in the monarchy were at least partially reduced, if not entirely pacified. Moreover, they laid the theoretical groundwork for Social-Democratic nationality policies. I will return to them later to evaluate to what extent the conditions for their implementation were present.

\subsection{Bauer's Position on the So-Called Nationalities Question \\ 2.2.1 Position on National Conflicts}

Bauer's stance on the national conflicts and decentralist aspirations of the Slavic peoples was unambiguously negative. Not only was this an expression of solidarity with the party leadership's official line, but it also had an emotional and psychological underpinning: Bauer was motivated by his fascination with German culture and attachment to the monarchy, in whose continued existence he believed and whose raison d'état he defended.

Bauer wrote The Question of Nationalities ... during the period when Austrian monopoly capitalism entered its imperialist phase. The propertied classes of Austria and Hungary intensified their oppression of classes and nations, for the economically weaker peoples served as cheap labour and ensured sales markets as long as they were kept in their place. The bourgeois nationalist parties - the Greater Germans and Christian Socials - bore witness to a rebirth of nationalism at the turn of the nineteenth and twentieth centuries. Nationalism, which had previously resonated, particularly among ethnic German workers, now appealed to the workers of other nations in Austria-Hungary. Bauer thought that nationalisms were on the rise because a flourishing capitalism had aggravated social contradictions. He emphasised the class character of national

72 Karl Renner developed them in the following works: Renner 1902, 1913, 1914, 1916, 1917, 1964 , and 2005. For our purposes, Renner's conceptions are secondary. I will only deal with them to the extent that their impact upon Bauer's programme necessitates it. 
struggles: while the bourgeoisie resorts to national values to preserve the existing social structures of capitalism, he argued, the working class turns them into a constituent part of its struggle for emancipation. ${ }^{73}$ However, this apt observation did not have the slightest influence upon Bauer's fundamental political position on the nationalities question. As previously alluded to, Bauer did not unambiguously advocate utilising the nationalities conflicts in the struggle for socialism. Nor did he, up until 1918, explicitly cite the right of nations to self-determination. ${ }^{74}$ For him, the pivotal goals were the abolition of national subjugation and alleviating the nationality conflicts that stood in the way of conducting effective Social-Democratic reform policies.

However, this did not mean that Bauer blindly disregarded the ambitions of subordinated nations to rebuild their state structures. Indeed, he took the possibility of an armed Polish and Ukrainian uprising into account. More than once, he warned Germans and Hungarians that national consciousness might grow among so-called non-historical peoples. He frequently appealed to the Poles, Czechs, and South Slavs to give up nationality policies that aimed for a breakdown of the monarchy. Bauer was convinced that preserving a huge national economic organism would serve the interests of the proletariat and all peoples of Austria-Hungary. In his view, it was the foundation for a fruitful class struggle, and it served as the basis for the nationalities policies of Social Democracy:

But those who long for a disintegration of Austria as the fulfilment of their national hopes now know how fragile this hope is. Every considered per-

73 When evaluating the role of classes as carriers of the national idea, Bauer did not manage to avoid premature judgements. In 'Deutschtum und Sozialdemokratie' ('Germanness and Social Democracy'), he demonstrated that the bourgeoisie had betrayed the national principle, and that the only 'true national politics' was being conducted by the working class. To prove this, Bauer invoked a rather facile argument: the workers' struggle to improve their material conditions leads to increased population growth and therefore to the growth of the German nation. This thesis drew on sociological theories of Darwinian origins that were popular among Social Democrats at the time and tended to overestimate the role of the demographic factor in the life of nations. Along with his belief that the greatness of a people could be measured by the greatness of its culture, this argument of Bauer's betrayed his Germanophile outlook.

74 Saage argues: 'With his major study on the nationalities question in the Habsburg monarchy, [Bauer] laid the foundations for the right of nations to self-determination. He thus established the positions of Social Democracy after World War I with regard to both the relationship of the multi-ethnic state to the nations and the question of Anschluss to the German empire' (our translation) - Saage 2009, p. 52. In my view, this is a bit of a stretch. 
son must strive to find a workable form of coexistence for the nations within the given state framework. No one can be allowed to withdraw from the struggle for a solution to the Austrian nationalities question by consoling himself with the belief that a great transformation in world politics will produce a solution to the national questions within this empire ... The workers, too, are unreasonably attributed an irresponsible catastrophist politics when called upon to place their hopes in the disintegration of this empire. ${ }^{75}$

It is also for political reasons that Bauer, like Renner, thought of the decentralist aspirations of the nations as senseless: he was sure that the emergence of new nations would prompt a lengthy struggle between Austria and Russia. This served as the basis for an erratic political prognosis. Bauer did not regard the independence movements of the peoples as such as a threat. Rather, he feared a potential clash between German and Turkish imperialism in the Balkans - or else, in case of an armed Polish uprising, Russian military intervention, which might spread into territories enclosed in Germany and Austria. This could have developed into a hotbed of war involving the whole of Europe.

It is necessary to add that under conditions of 1907, Bauer did not expect the demise of the monarchy and rise of independent nation states. He cited the following factors to substantiate his position: (1) The peoples of AustriaHungary are economically and politically too weak to survive and defend themselves in independent states; (2) The industrial bourgeoisie is interested in preserving the monarchy. This is because of its economic and financial connections; (3) Because of the influence of the church and the power of tradition, the bourgeoisie and the peasantry endorse the multinational state.

Let us attempt to explain the reasons for Bauer's positive attitude towards the monarchy and his aversion to the decentralist politics of the Slavic peoples. The fact that he did not like the Slavs is of lesser importance. It is fair to assume that his views were crucially influenced by the classical Marxists' beliefs in the endurance of vast national territories and the revolutionary role of the consolidated working class. Bauer's commitment to the internationalist idea also had some significance. However, it is also important to note a factor that has already been mentioned on several occasions: namely his fascination with Germany's achievements and culture. ${ }^{76}$

75 Bauer 1996, p. 403 .

76 Compare Mozetič 1987, p. 226. Mozetič evaluates Bauer's position as a manifestation of German nationalism. Although I do not share his harsh judgement, I concede that Bauer 
When defending the nationalities policies of Social Democracy at party congresses, Bauer passionately argued against the Czech separatists who demanded national trade unions. The issue of federal structures had been settled in 1897, yet the argument about local trade unions continued. Like Renner and Friedrich Adler, Bauer regarded Czech separatism as a great danger for the workers' movement in the monarchy and opposed splitting up the unions. He based his argument on the common economic interests of the international working class, the necessity to preserve a centralised financial sector and unity of administration, and the need to pursue a common social politics. In 1910, when the breakup of the unions was a long accomplished fact, Bauer defended the territorial principle against Czech demands to base the trade-union movement on the personal principle. ${ }^{77} \mathrm{He}$ regarded the territorial principle as the last effective means to preserve the unity of the proletarian movement.

In this context, Bauer's position on the Polish question in the monarchy is remarkable. He did not attach any importance to Polish independence within the context of Austro-Hungarian politics. Nor did he fear a war between Austria and Russia over Poland's independence. Although he was critical of Luxemburg's thesis that Poland's economy was insufficiently autarkic, her suggestion to concede national-cultural autonomy to solve the Polish question was where their positions overlapped. Luxemburg envisioned autonomy within the framework of a Russian state that would arise from the ruins of the Tsarist Empire. For Bauer, autonomy would be granted in Russia, Poland and Austria. This solution to the Polish question was consistent with Bauer's nationalities programme. Its essence was to concede national-cultural autonomy to the nations of AustriaHungary and suppress their pursuit of state independence.

\subsubsection{The Programme of National-Cultural Autonomy}

Bauer drew the basic premises of this programme from some of Renner's texts, where the author had declared that autonomy was a prerequisite for

often underlined the leading role of the German nation and its cultural mission in Europe. His proclivity to link the class struggle of the proletariat with German national interests is documented in many of his texts. It is also noticeable in articles in which he analyses German-Czech relations and Czech national demands. Concerning these, Bauer endorsed the linguistic demands of the Czechs.

77 The personal principle, which was counterposed to the territorial principle, was the subject of much argument in the Austrian Social-Democratic movement. Not the individual's place of residence, but subjective identification with national ties and descent was to decide over one's nationality. 
the transformation of the monarchy into a democratic multinational state. His proposition was based on four key premises:

1. The nation is, above all, a community of culture; the unity of economic and social interests plays a secondary role for the nation.

2. The nation has no significance for the process of state formation. This thesis served to justify the introduction of the personal principle as a distinguishing criterion of the nation. ${ }^{78}$

3. The development of capitalism leads to the formation of vast state and economic territories. Hence, the existence of small nation states is an anomaly.

4. The nationalities question is solved gradually in the course of the fundamental democratisation of the legal system and state order.

Renner paid particular attention to issues concerning the legal system and state order. He incorporated an outline for a two-dimensional federalism into his proposal: the state would be sub-divided into provinces of greater ethnic homogeneity and communities based on the personal principle (according to this principle, all citizens of a given nationality belonged to that nation irrespective of where they lived). The community would serve the protection of minority rights - to be sure, Renner primarily had the rights of dispersed Germans across non-German territories in mind. ${ }^{79}$ In his vision, ethnically homogeneous autonomous territories would simultaneously constitute a basic element of the federal state and the federation of national states. The national association as a whole would preserve its right to full cultural autonomy, representation in the national administration, and self-administration by virtue of its statehood. The autonomy principle rested on three premises: unity of organisation; distribution of legal responsibilities; and type of federalisation. It is significant that Renner, contrary to his premise, considered the unity of economic and social interests to be a foundation for creating autonomous countries. One might rightly accuse him of introducing the personal alongside the territorial prin-

78 Compare Konrad 1976, p. 90.

79 He explicitly wrote about this in 'Grundlagen und Entwicklungsziele' ('Foundations and Development Aims'): 'We do not want to divide or dominate anybody - we want the national aspect to be separated from the political aspect; Whether dualism, trialism ... pentarchy ... or chiliarchy ... from a national standpoint, they are all the same to us. Nonetheless, all Germans between Bodenbach and Oršava ought to form a legally recognised cultural co-operative that has the sovereignty to impose individual taxation, and the power to build primary schools, secondary schools, and high schools wherever the Germans want and need them' (our translation) - Renner 1906, p. 239. 
ciple through the backdoor. However, the serious mistake about his concept was the following: Renner took for granted that individual countries pursued the same economic and political interests as the monarchy and that state unity should therefore be preserved as the only favourable solution. As Helmut Zimmermann correctly observes, this led to the following conclusion: 'Reducing matters to cultural autonomy not only allowed for existing economic conditions to persist, but also perverted relations between different national groups of workers into open economic hostility' (our translation). ${ }^{80}$ It is worth highlighting that Renner's model only contained an ostensible equality of nations the principles of proportion and independence were limited to cultural questions such as language, the development of the education and school system, science and art. They did not apply, for instance, to political public life, i.e. the appointment of official posts. ${ }^{81}$ It is also noteworthy that there was no mention of the interrelationship between the national struggle and the class struggle. Renner assumed that democratic reforms in the bourgeois multinational state would stave off the hunger for socialism for an extended period. As late as 1918, when there was no longer any chance to preserve the monarchy, he compulsively defended the draft for national-cultural autonomy (even as president of the Second Austrian Republic, he had still not come to terms with the loss of Austria's territorial outline).

The unifying element between Bauer's socio-political thought and Renner's scheme was their belief that political democracy would solve the national question. ${ }^{82}$ Parliament would become a tool for reform beneficial to the quarrelling peoples of the monarchy. This was rooted in the idea that constitutional guarantees of national equality would convince the nations to relinquish their demands and mutually accept their respective national goals. Moreover, Bauer and Renner believed that institutional and democratic forms of social life would allow Austria-Hungary to reduce the nationalities question to the cultural sphere. Four points related to Renner's ideas guided Bauer's conception of national-cultural autonomy. Firstly, he advocated a separation of state and nation. Secondly, he proposed the exterritoriality principle as a means to determine nationality. Thirdly, he wanted to limit autonomy to the cultural sphere. Fourthly, his thinking was steeped in Greater German categories, coupled with a concern that the German nation might be slavicised.

\footnotetext{
8o Zimmermann 1976, p. 385 .

$81 \quad$ See Kann 1973, p. 6.

82 Compare Mommsen 1963, p. 202.
} 
However, the two conceptions of autonomy were not fully congruent. Renner's proposition was based on research of the legal and institutional relations between peoples. Bauer, conversely, took an analysis of the economic and political conditions of different classes as a starting point. ${ }^{83} \mathrm{He}$ arrived at an astonishing conclusion: the economic interests of all Austro-Hungarian social classes, especially those of the propertied classes, militated for the introduction of autonomy in Austria-Hungary; all classes had an objective interest in it. ${ }^{84}$ From this, Bauer concluded that autonomy should be adopted into the programmes of all nations, classes, and parties that had a stake in the continued existence of Austria. Bauer wanted his postulate to be understood in this way: the bourgeoisie defends the multinational state in the name of its economic and political interests, and the proletariat should equally support it to protect its own interests. Not only did Bauer disregard the conflict of interests between classes in any capitalist state, he also ignored the response of oppressed nations. Hence, his judgements missed the historical truth, namely that the Czech and Polish bourgeoisie and the Czech industrial proletariat were sceptical of the notion of autonomy.

According to Bauer's premise, the Social-Democratic movement had to act within the existing constitutional framework. He therefore regarded the struggle for autonomy as a central objective of Social-Democratic nationalities policy. Bauer believed that conceding autonomy might relieve tensions within the working class and facilitate united struggle within the given legal framework. Bauer wrote:

[T] he state should limit itself to the protection of those interests which are a matter of indifference in national terms, but are common to all nations. Thus, national autonomy, the self-determination of nations, necessarily becomes the constitutional programme of the working class of all nations within the multinational state. ${ }^{85}$

The slogan, 'national autonomy is a necessary goal of the proletarian class struggle', ${ }^{86}$ succinctly expressed his confidence in the continued ability of

83 Compare Zimmermann 1976, p. 389. Hanisch writes that Bauer broadened Renner's conception by giving it a wider historical, theoretical, and political context - see Hanisch 2011, p. 101.

84 Compare Kulemann 1979, p. 128.

85 Bauer 1996, pp. 255-6.

$86 \quad$ Bauer 1996, p. 258. 
the nations to survive without the necessity for revolutionary transformation of the existing state.

The question arises as to what Bauer meant by national-cultural autonomy. Much like Renner, he conceived of the autonomous association as possessing its own state structures, i.e. a parliament, government, state budget, culture and education. The state authority would exercise self-administration. Each federal state would preserve national and administrative unity as part of a federation with a common fiscal system. Their official language would be German. Administrative tasks, the central economy, and the military would be left to the individual federal states. The state ought to guarantee its citizens the free development of national culture, education, institutional forms, and social life. ${ }^{87}$ This concept of national-cultural autonomy, however, excluded political autonomy. It was assumed that states would not strive for independent national statehood if they were granted national gains within a multinational structure. According to Bauer and Renner, national-cultural autonomy would be based on the exterritoriality principle, i.e. individual definition of nationality irrespective of residence. 88

Bauer's suggested concept of national-cultural autonomy aimed to preserve the multinational state, transform the monarchy into a democratic state with a federal structure, abolish special privileges, and in this way secure the equality of nations. It was by far the most progressive suggestion to solve the nationalities question in Austria at the time, even if it did not meet the expectations of the oppressed peoples that had been fighting for independence for years. Its objective was similar to that of Renner's model: reform rather than transformation of the class structure in the bourgeois state. According to this plan, the preservation of the multinational state was a precondition for waging the class struggle under the leadership of the Social-Democratic party. As Mommsen points out, the problem with the internationalist ideology that Austrian Social Democracy, including Bauer and Renner, had to wrestle with 'lay, of course, in that it presupposes that national interests are essentially limited to the cultural and linguistic

87 As Hanisch writes: 'This major, long-term project demanded radical constitutional reform, a complete reconstitution of Austria. The "centralist-atomic" regulation, as Bauer called the December constitution of 1867 , was to be replaced by an "organic regulation"' Hanisch 2011, p. 101.

88 Bauer rejected the territorial principle on the grounds of migration movements, the division of economic territories, and the danger of minorities being 'swallowed up'. In 1908 , he identified technical and legal difficulties as standing in the way of the personal principle. In Die soziale Gliederung der österreichischen Nationen (The Social Structure of the Austrian Nations), he supported the territorial principle. 
realm, while economic questions have an international character by nature' (our translation)..$^{89}$ Although questions of language and education played an important role in the Habsburg monarchy, the assumption that national ambitions could be confined to the cultural realm was illusory. Similarly, Bauer and Renner's belief that the economic community of interests uniting the peoples of Austria-Hungary could offset their separatist tendencies was wishful thinking.

Voices from the Marxist camp did not spare the concept of national-cultural autonomy from criticism. It was approved neither by the SDAP nor by the nationalist parties, where Ignaz Seipel was one of many who viewed it with contempt. The policy was criticised for disregarding the socio-political conditions of Austria and Europe, or else for its conservative stance towards the independence movements. Stalin reproached Bauer for failing to explicitly mention the right of nations to self-determination, while Lenin accused him of German nationalism. ${ }^{90}$ Kautsky took a particularly critical view in a series of articles printed in Die Neue Zeit (1908) and a pamphlet, Nationalität und Internationalität (Nationality and Internationality, 1908). While conceding that autonomy was crucial for working-class organisation in the struggle against nationalism, he disagreed that one could achieve it in a multinational state. ${ }^{91}$ In Kautsky's opinion, Bauer underestimated the strength of the movements for self-determination. As early as 1908, Kautsky predicted the demise of the monarchy. In his critique of autonomy, he considered two factors: economic differences and language. Kautsky emphasised that autonomy would not suspend national conflicts. He believed that they resulted from the unequal economic development of nations, which necessarily upset the equal distribution of financial means for cultural and educational purposes. Conversely, he presumed that language was a basic criterion for a nation's development - he saw the future of nations in communities of language. In his reply to Kautsky, Bauer accepted that national-cultural autonomy was only a half-solution, given that the principle of legal equality for self-administration did not revoke economic

89 Mommsen 1963, p. 10.

9o Stalin 1953, p. 338.

91 Kautsky wrote on Austria-Hungary: 'Austria itself will then become superfluous to those nations that still today think that they need it. If the whole of Europe were structured according to nations and economic areas - what place would there then be for a federal state in a federal state? And if all nations of contemporary Austria join together with their fellow language speakers outside of the existing territory of the Empire to form entities that are autonomous for the purpose of language culture, what elements remain for a specific multinational state?' - Kautsky 2010, p. 163 . 
divergences and national conflicts of interest. Nonetheless, he defended it as a principle that would guarantee the preservation of the state. In response, Kautsky accused Bauer of fetishising the state as a goal in itself instead of regarding it as a tool in the class struggle.

The SDAP majority also judged the model of national-cultural autonomy negatively. The prevailing view was that no suggestions for reforming the state should be made in parliament. In light of strong national antagonisms, and because each respective country aspired to extract more concessions at the expense of others, such reforms might lead to a disaster and the fall of the monarchy. This outcome, in turn, would render the party's strategic line invalid. One should not forget that the SDAP, which was embroiled in the struggle for universal suffrage at the beginning of the twentieth century, did not yet represent a serious political counterweight to the Christian Social and Greater German camps. Arguments about the liberation of the Slavic peoples emerging in the ranks of Social Democracy only complicated matters further. As Mommsen states, even the suggestion to divide the state into districts to protect the rights of Czech Germans was strongly opposed by Social Democrats. ${ }^{92}$ The Czechs disapproved of the proposal to increase the state budget for culture contained in Bauer's model. In their view, this would primarily benefit the German population. Conversely, they were eager to get subsidies from Austria. The government successfully suppressed their efforts, as did the German-Austrian Social Democrats. One might even speak of a certain alliance between Social Democracy and the crown during the period leading up to Word War I. In contrast to the peoples of the monarchy, they both represented centralist trends. Centralist tendencies were also manifest in both autonomy models, even if they doubtlessly had a progressive character in Austria at the time. In 1920, Hans Kelsen harked back to one of their suggestions: ethnically homogeneous autonomous regions were to become a fundamental element of the national federation and the federation of national states. His texts inspired the co-founders of Austrian statehood.

\subsubsection{Remarks on National Assimilation}

The assimilation process, which comprised all ethnic groups equally, was a significant phenomenon of the Habsburg state. The slogan of 'national assimilation' became a cause of disagreement between German-Austrian and Czech Social Democrats especially after 1897. At the turn of the nineteenth century, increasing levels of Czech economic migration to Vienna and Lower Austria 
provoked fears of slavicisation of ancient German territories among ethnic Germans. The Czechs watched the trend of migration with displeasure, quite justifiably regarding it as a cause for the economic and political weakening of their nation. The notion that national-cultural autonomy was a tool to increase migration of non-German groups was an important reason as to why the Czech Social Democrats viewed it with caution. ${ }^{93}$

Understandably, Bauer's conception of assimilation and the conclusions he drew from it only reinforced the Czech socialists' fears. Bauer gave assimilation a distinctly German flavour and made it part of his programme to preserve the monarchy. While he did not dedicate much theoretical attention to it, many of his statements at party congresses testified to his great hope of overcoming national conflict through assimilation. He tied this not only to autonomy as a programme for today, but also to the merging of nations in the future.

Bauer only undertook a sociological analysis of the assimilation process in a 1912 article entitled 'Die Bedingungen der nationalen Assimilation' ('The Conditions of National Assimilation'). It is where his differences with Kautsky became apparent. Kautsky depicted the foundations of assimilation in a simplified manner, i.e. a relatively straightforward process whereby the language of an ethnic majority is adopted. In contrast to Kautsky, Bauer emphasised the complexity of assimilation. For him, it was a long and complicated historical process during which diverging national characteristics, personality types, culture and customs had to be considered. Bauer was aware that there was no clear dividing line between assimilating and surrendering one's national identity. Hence, he wrote that 'national assimilation, as we have demonstrated in our fifth assimilation law, is always assimilation only to fellow members of the same class. National coercion is the subjugation of one class to the will of another, regardless of whether the ruling class uses economic or state power to do violence to a minority' (our translation). ${ }^{94}$ Bauer based his sociological assimilation laws on the relations in Austria-Hungary: they testified to the singular, one-dimensional character of the assimilation process, which amounted to the incorporation of an ethnic minority into the majority in each respective class.

93 Compare Mommsen 1979b, p. 211.

94 'Die nationale Assimilation ist, wie wir in unserem fünften Assimilationsgesetz gezeigt haben, immer nur Angleichung an Klassengenossen, die nationale Nötigung ist Unterwerfung einer Klasse unter den Willen einer anderen Klasse, sei es nun, dass sich die herrschende Klasse ihrer wirtschaftlichen Macht oder dass sie sich ihrer Staatsgewalt bedient, um der Minderheit Gewalt antun' - Bauer 1980d, p. 621. 
Bauer cited demographic aspects such as small size and dispersal, but particularly cultural features such as similarity in language, religion and culture as factors that accelerated this process. He attached crucial importance to the latter. His analysis was especially valuable insofar as he highlighted the degree of differentiation that existed within the respective classes and social groups during the process of assimilation. He found that the assimilation process in oppressed countries primarily involved the propertied classes, which merged with the ruling classes of the oppressor nation provided that they could benefit from their economic and political position. As to the peasantry and proletariat of the oppressed countries, their economic and cultural levels determined the pace of the assimilation process: peasants assimilated faster and with less difficulty if their economic and cultural levels were more advanced. The exact opposite was true for the working class.

We can conclude from our observations thus far that Bauer regarded assimilation in a multinational state as a desirable process. Therefore, he suggested integrating the slogan for national assimilation into the nationalities programme of Social Democracy. Although it contradicted the personal principle that he supported, Bauer bypassed this inconvenient fact for political reasons. As a politician defending the concerns of Austrian Social Democracy, he hoped that assimilation would proceed in one direction only: he expected that non-German peoples would assimilate to Germany due to its economic and cultural superiority. When German and Czech Social Democrats fought over the latter group's proposal to open Czech minority schools, it should therefore come as no surprise that Bauer opposed the idea. He claimed that it would upset the peaceful assimilation process and would aggravate the nationalities conflict between Germans and Czechs, who made up 26 percent of the Vienna population. Notably, this did not stop him from establishing middle schools for the German population in Czechia. ${ }^{95} \mathrm{~A}$ similar inconsistency is apparent in Bauer's position on Czech workers. On the one hand, he opposed their forced Germanisation, fearing that it might put the German minority in Czechia at risk. In contrast, he called on Social Democrats

95 The following picture emerges from Bauer's discussion of the school system: minorities that assimilate (non-historical nations) should not have their own schools, while minorities that assimilate (historical nations, in this case the Germans) should have the right to national schools. On mixed territories, minorities that do or do not assimilate should have the right to form national and bilingual schools - in the Sudetenland, for instance, there should be both German and Czech schools. This education system model was clearly biased towards Germans. As to Bauer's suggestion to establish German schools in Czechia, compare Mommsen 1963, p. 211. 
to support professional training and raise the cultural level of Czech workers in Austria, arguing that it would accelerate the process of their assimilation with Germany. It is justified to say that Bauer's entire line of argumentation with respect to national assimilation testified to his vivid aversion towards the oppressed peoples' decentralist aspirations. What is more, it marked the transition of Austrian Social Democracy towards nationalist positions.

\subsection{The Programme of the Left and the Demise of the Monarchy}

The conflict between Austria and Serbia that followed the annexation of Bosnia and Herzegovina made the Austrian Social Democrats aware that the unresolved nationalities question might lead to a world war in the near future. With the exception of a tiny group of imperial officials and a number of state-loyal Social Democrats, few had doubts that a world war would result in the disintegration of the Habsburg Empire. Bauer was one of the few who anticipated such a historical development as early as 1908: he believed that the outbreak of the war would trigger a wave of revolutions across Europe, inevitably leading to the demise of multinational states. ${ }^{96}$ In 1911 , he warned:

Austria, too, will be caught up in these upheavals. The national struggles and the relationship to Hungary push for the whole of the imperial structure to be overturned. Either Austria will be transformed into a federal state comprising of autonomous nations, or it will cease to exist. ${ }^{97}$

The outbreak of war weakened the party-internal bonds of the SDAP and deepened the differences between Bauer's and Renner's nationalities policies. In his wartime texts, Österreichs Erneuerung (Austria's Renewal) and Marxismus, Krieg und Internationale (Marxism, War and the International), Renner continued to defend the principle of the multinational state. This was, on the one hand, an expression of his old belief that Social Democracy could successfully continue its politics within the existing constitutional framework. But on the other hand, it also betrayed his opposition to changing the sociopolitical order and his affirmative stance towards the capitalist state - an attitude that Bauer harshly criticised. The task of Social Democracy in wartime, Bauer argued, was to prepare the masses for the forthcoming revolution, not to defend a state that would disintegrate due to the decentralist efforts of the

96 See Bauer 1996, pp. 5-6.

97 Bauer 1975d, p. 940. 
Slavic nations. ${ }^{98}$ The victorious 1917 socialist revolution in Russia further polarised positions in Social Democracy. Renner continued to defend his old point of view, while Bauer inspired a left group to proclaim a nationalities programme. For the first time, the SDAP - or rather, a faction of the party - pleaded for the right of nations to self-determination. Even so, the programme of 1917 did not have the slightest significance: as early as January 1918, it emerged at a delegates' congress of the Austrian, Czech and Polish left in Vienna that the Austrian Social Democrats, including Bauer, never fully supported the right to selfdetermination. The left adopted a new nationalities programme at this conference. Although it endorsed Czech and Polish aspirations to independence and conceded the right to self-determination to the Slavic peoples, it did not represent a significant turn in the nationalities policy of Social Democracy. ${ }^{99}$ Rather, it was the old federalist idea dressed up in new garb - an attempt to preserve the great economic territory either through union or through the Greater German solution. The programme envisioned the following points:

1. Austria-Hungary would be divided into seven territories according to the language principle: German, Czech, Polish, Ukrainian, South Slavic, Italian, and Romanian regions; these communities would decide their national identity in a plebiscite.

2. In each territory, the national assembly would decide what type of constitution to adopt and what neighbourly relations to pursue by virtue of universal suffrage.

3. Political autonomy would not imply complete independence of the formerly Austro-Hungarian peoples; new organs would be convened to regulate economic questions in co-operation. ${ }^{100}$

The programme upheld the idea of a Social-Democratic party that would unite national parties in a federal structure and on an equal footing. To justify this

98 As Leser writes, the majority of the party did not find Bauer's 1917 speeches credible. Many Austrian workers regarded the Slavic peoples' struggle for independence as a betrayal of class interests. See Leser 1964, p. 20.

99 My assessment is mirrored in Mommsen 1979, p. 216; Panzenböck 1985, p. 83; Kulemann 1979, p. 210; Hautmann 2007, p. 93. As Hautmann demonstrates, the programme factually meant that the nations of the Austro-Hungarian monarchy would be granted the right to decide their future, which included the right to create sovereign countries. In Hautmann's opinion, the left's agreement on this question was the only way to justify its programmatic demand to annex the German-speaking territories to democratic Germany.

100 See Bauer 1980g, p. 951. Compare Panzenböck 1985, p. 83. 
model, it stressed the international character of the class struggle and the necessity of the working class joining forces for the right of nations to selfdetermination. ${ }^{101}$ Ten months later, Bauer referred to it in the Arbeiter-Zeitung, conceding to the Slavic peoples the right to choose their own future. However, it is noteworthy that Bauer did not emphasise the principle of national selfdetermination. The idea of Austria's annexation to the German Reich (the Anschluss idea) represented an obstacle in this respect: it was inconsistent with national independence and the democratic institutional solutions contained in the left's proposed model. ${ }^{102}$ The only significant modification to Bauer's 1918 position on the nationalities question was his break with the notion that only socialism could realise the right of nations to self-determination - this also testified to his non-doctrinaire approach. From then on, Bauer linked this right with the victory of democracy in Europe. ${ }^{103}$

The 1918 nationalities programme of the left intensified the polemics between Renner and Bauer, with Max Adler taking Bauer's side. Renner attacked the programme, arguing that the formation of new nation states after the fall of the monarchy was a 'reactionary utopia'. Convinced that the proletariat would gain the most by backing the policies of the existing imperialist state instead of getting embroiled in national struggles, he supported the war drive of the party leadership. According to Renner, the future of Western Europe lay in establishing vast economic territories, whereas that of Eastern European peoples lay in territorial and economic union under German patronage. Renner defended this idea as late as 1922, when he conceded sovereignty to the middle and East European states yet continued to advocate economic and cultural attachment to Germany. Although he rightly reproached Bauer and the left for their Greater German orientation, Renner failed to acknowledge nationalist elements in his own thinking. His main argument for preserving the unity of the Austria-Hungarian Empire was that it would preserve the interests of national minorities, especially the German minority in Czechia. Bauer was far more realistic in evaluating the possibilities of saving the Habsburg state in 1918. In view of Austria's weakened position, the changing political balance of forces in Europe, and the revolutionary wave moving west, he expected the imminent fall of the monarchy. This is not to imply, however, that he gave up all hope in

101 The Hungarian Social Democrats did not accept the programme of the left. Instead, they defended Hungary's integrity against the nationalities it oppressed. This led to a war against Czechoslovakia and Romania and contributed to the defeat of the Hungarian workers' movement.

102 Compare Mommsen 1963, p. 215.

103 Ibid. 
Austria-Hungary's potential salvation. On the contrary, he claimed as late as 1918 that, as long as German imperialism prevailed, the only alternative was to preserve the old structural framework of the party and work out a reform programme for the multinational state. Towards the end of the war, his position was close to the right wing of the party. The sole difference between the two leading Social Democrats was that Bauer accepted the fall of the monarchy, while Renner believed in its rebirth until the end.

As expected, the war led to the disintegration of Austria-Hungary. Investigating the causes of its demise in The Austrian Revolution (1923), Bauer conceded that 'the great old Empire, the great old economic unity was not destroyed by the social revolution of the German-Austrian and the Magyar proletariat, but by the national revolution of the Czech, the Polish, and the Jugo Slav bourgeoisie.'104 In accordance with his own definition of the nation, he attributed the fall of Austria-Hungary mainly to a psychological factor, 'the old tribal feud between the nations', rather than to the economic causes of the nationalities conflicts. ${ }^{105}$ On 3 October 1918, the parliamentary fraction of the SDAP under Bauer's leadership adopted the right of the Slavic nations to self-determination. In its appeal, it demanded the unification of all German territories in Austria into one state that would self-determine its relations to neighbouring countries, especially Germany.

After the demise of the monarchy, the question for Austria's national identity amounted to whether Austria should maintain its national independence or join the Reich. ${ }^{106}$ Austria had always been a country characterised by much stronger German influences than the sheer size of its German populace suggested. An Anschluss to Germany was in the interest of the German population, which was the decisive aspect for German-Austrian Social Democracy when it accepted the Anschluss proposal at the plenary assembly on 6 June $1917 .{ }^{107}$ Of all party leaders, Bauer advocated it with the greatest passion. He argued that

\footnotetext{
104 Bauer 1925, p. 73.

105 Kulemann 1979, p. 48.

106 The demand for Austria's annexation by Germany appeared in Austrian Social-Democratic thought as early as 1880 - See Konrad 1978, p. 25 .

107 According to Fröschl and Zoitl 1985, p. 242, Austrian attitudes towards the Anschluss idea varied across different social classes. During the times of the monarchy, sections of the bourgeoisie were in favour of annexation by Germany, while other sections pleaded for national independence. The division became greater after 1918. The peasantry and petty bourgeoisie loathed the Protestant Prussians. The working class was generally opposed to German chauvinism and imperialism, yet parts of it came out in favour of annexation. The intelligentsia was overwhelmingly the mouthpiece of German nationalism.
} 
three German countries should be created - an Inner Austrian, German Czech, and a Sudeten German territory - and returned to the home country. ${ }^{108}$ Indeed, a proposal for this type of reorganisation already appeared in The Question of Nationalities as an alternative to national autonomy. For Bauer - as for Renner - the idea of Anschluss had a national dimension (community of culture, blood ties), but also political, economic, and revolutionary aspects. It is mainly for these reasons that he would obsessively revisit this idea - even after the Anschluss proposal had been rejected in the Treaty of Saint-Germain-en-Laye of 1919. In 1923, Bauer continued to see two possibilities: 'Supranational federation of the Danubian peoples or national unity of the Germans; restoration of the Hapsburg Monarchy or fusion [Anschluss] with the German Republic'.109

A brief comment might serve to sum up these observations. The proposals put forward before World War I (national-cultural autonomy, cultural assimilation) and during the war (Anschluss) reflected the transformation of Austrian Social Democracy towards nationalist positions. Because these positions effectively meant a denial of the right to national self-determination, they did not meet the expectations of the subordinate nations of Austria-Hungary. Ultimately, the solution to the nationalities question was decided by the respective countries' long-time efforts to rebuild their statehood, the defeat of the Austrian army on the war front, and the desire of the masses to end the war and national conflicts. ${ }^{110}$

It is worth shedding light on a particular belief that was intrinsic to Bauer's position: national objectives, when pursued by the proletariat, can become the proletariat's overriding objectives (we will examine this in more detail in

108 It is necessary to emphasise the fundamental difference between Bauer's and Hitler's understanding of Anschluss, the annexation of Austria to Germany. Bauer did not propose a simple incorporation of Austria into the Reich, but rather the creation of a body of German states (based mainly on common economic and financial policies) in which all states would retain far-reaching autonomy in domestic questions.

109 Bauer 1925, p. 282.

110 As anticipated by Bauer, independent nation states were formed. Yet questions of peaceful co-operation between these states in the capitalist era of competition over sales and labour markets have lost none of their relevance. Today, there is no doubt that Bauer's suggestions for reconciling the nations are mainly of historical interest. However, I maintain that national-cultural autonomy remains the most effective way to defend minorities against the centralisation of power in a nation state. The demands of Hungarian politicians in Slovakia, who in 1996 called for the introduction of autonomy in the spheres of culture and education, testify to this. The same is true for Silesians in Poland who do not identify with the Polish nation. 
Chapter 7). The vision of a 'United States of Europe',111 which informed The Question of Nationalities and Social Democracy, is certainly close to the hearts of Europeans today. In Bauer's theory, it is true, this vision was intrinsically linked to a socialist future - yet that does not diminish its grandeur.

111 See Bauer 1996, p. 414. 